\title{
THE EFFECTS OF A CHANGE IN MARKET ABUSE REGULATION ON ABNORMAL RETURNS AND VOLUMES: EVIDENCE FROM THE AMSTERDAM STOCK MARKET
}

BY

TYAS PREVOO* AND BAS TER WEEL***

\begin{abstract}
Summary
The Market Abuse Directive came into effect on 1 October 2005. One of its purposes is to reduce illegal insider trading and leakage of information prior to official releases by increasing penalties. Applying an event study approach to a dataset of almost 5,000 corporate news announcements, the analysis reveals that the information value of announcements, measured by the announcement day abnormal return and abnormal volume, is not significantly different after the new regulation than it was before although the number of releases has increased significantly. Trading suspicious of illegal insider trading and leakage of information, measured in terms of cumulative average abnormal returns and volumes for the 30 days prior to the news announcement, has significantly declined for small capitalization firms, for announcements containing information about alliances and mergers and acquisitions and for firms in the technology sector.
\end{abstract}

Key words: Market abuse, Insider trading

JEL code: G14

\section{INTRODUCTION}

As of 1 October 2005, the Market Abuse Directive (MAD) is in effect. This set of regulations concerns the publication of price sensitive information by firms listed on the Amsterdam stock market. Firms are obliged to publicly disclose information, which is considered to have an effect on the stock price of its listing. The most prominent change of MAD is that penalties for insider trading have been increased substantially. In addition, the supervision of the publication of price sensitive information has been transferred from Euronext Amsterdam to the Netherlands Authority for the Financial Markets (AFM).

The aim of this research is twofold. First, it investigates the effects of MAD on the extent of stock market behaviour prior to corporate news

\footnotetext{
* Maastricht University, Maastricht, The Netherlands

**Corresponding author: CPB Netherlands Bureau for Economic Policy Analysis, The Hague, The Netherlands e-mail: b.ter.weel@cpb.nl

We benefited from the comments made by seminar audiences at the Netherlands Authority for the Financial Markets (AFM) and the Financial Services Authority (FSA) in Britain; and from very useful suggestions by two referees, Arnoud Boot and Hans Degryse to improve the paper.
} 
announcements, which is suspicious of illegal insider trading. One purpose of MAD is to increase market integrity and confidence. This can be achieved by making the market "cleaner". So, the first question is whether or not MAD succeeded in decreasing the prevalence of illegal insider trading on the Amsterdam stock market. Second, it investigates a change in the general information level of announcements due to the change in regulation. In fear of sanctions from a tough regulator for withholding information from the market, firms may just publish as much information as possible, regardless of whether the news is relevant. So, the second question is whether the information content of corporate news announcements has changed after MAD.

The economic literature has little to say about the effectiveness of insider trading regulation in the Netherlands. Kabir and Vermaelen (1996) examine the effects of regulation introduced in 1987 restricting insider trading in Amsterdam and indicate that although trading by insiders did decrease in the restricted period, overall liquidity decreased as well, which is not a desired effect of the regulation.

We examine the research questions using a set of almost 5,000 corporate news announcements, alongside stock prices and volumes. Using an event study approach, the results are consistent with the hypothesis that the cumulative average abnormal returns and volumes prior to the date of news announcements are lower after MAD. This indicates that illegal insider trading is less prevalent under the new directive, but still present. The second question, that average abnormal returns and volumes on the announcement day have changed under MAD, is rejected. Although the data show that the number of announcements released by firms is larger after the new regulation, the average information content of these announcements has not decreased. If anything, it seems to have increased slightly, although not significantly so. The results suggest that MAD has made markets cleaner, but not at the expense of information overload. So, overall efficiency seems to have increased in the Amsterdam stock market after the introduction of new legislation.

Previous event studies often focus on large frequently traded firms, given that data on these firms is more easily available. The impact of insider trading regulation might however depend on firm size too. Elliott et al. (1984) note that smaller firms are not followed so closely by analysts, which might give insiders more opportunities to reap benefits by trading on inside information. For this reason, the analyses in this paper are also applied to sub-samples, which are divided by capitalization size. The Amsterdam stock exchange contains three size classes. The results from these analyses show that small capitalization firms drive much of the effects shown for the total sample. MAD does not seem to have altered stock market behaviour surrounding news announcements for larger firms. Dividing the market into different 
industries suggests that especially the technology sector has become cleaner, with no significant changes found for the other sectors.

The literature shows a large diversity in the way the impact of changes in insider trading regulation is estimated. Different types of corporate news announcements are used. Different types of news may have different characteristics influencing market behaviour in different ways; the effects of regulation may also differ along this dimension. This research uses data containing various types of announcements, allowing to distinguish the effects of MAD by announcement type. The effects are shown to be strongest for announcements containing news on alliances, takeovers and mergers and acquisitions. The apparent leakage of information prior to the announcement date in terms of pre-announcement run-up in prices and volumes has significantly decreased after MAD is in effect.

Finally, previous work on stock market behaviour surrounding news announcements often uses absolute returns to explain and find patterns of illegal insider trading, whereas making a distinction between bad news and good news allows for a comparison between the magnitude of the price reaction to bad news announcements and that of good news announcements. The results show that the market has become cleaner especially in the bad news segment, which suggests that bad news messages have been published sooner after MAD is in effect.

This paper is set up as follows. The next section describes the changes in market abuse regulation in the Netherlands. The approach of estimating the effects on stock market behaviour is explained in Section 3. Section 4 describes the data and gives a number of descriptive statistics. Section 5 reports the main results of the analysis. Section 6 shows the robustness of the estimates and Section 7 discusses the findings and concludes.

\section{BACKGROUND}

The Act on the Supervision of the Securities Trade 1995 (WTE) is the principal act governing the supervision carried out by the Netherlands Authority for the Financial Markets (AFM). The WTE provides that the AFM can exercise supervision by means of statutory powers to carry out investigations and inspections, monitor compliance and obtain information that are laid down in the act. As of 1 October 2005, the Market Abuse Directive (MAD) is incorporated in the Netherlands into the WTE (Articles 45-47) and the Market Abuse Decree. The aim is to sharpen, expand, and harmonize the existing European regime and to achieve improved protection for market integrity within Europe.

The results of the implementation of MAD are an expansion of the prohibition against market manipulation and the transfer of the supervision of the publication of price-sensitive information by listed companies from 
Euronext Amsterdam (previously dictated by rule $28 \mathrm{~h}$ of the Fondsenreglement) to the AFM. Additionally, a transparency regime for publicists of investment recommendations and a requirement for securities institutions to report a reasonable suspicion of trading with insider information or market manipulation (the so-called klikplicht) have been introduced. Finally, the existing provisions regarding trading with insider information, the reporting requirement for "insiders" and the insider regulations are adapted with respect to the prior legislation.

The rulemaking contains the requirement for issuing companies whose securities are admitted to trading on a regulated market in the Netherlands, to immediately (i.e., without delay) publish price-sensitive information. The publication of price-sensitive information should occur through the publication of a press release. It is the responsibility of the issuing company to determine the best practice for an immediate and simultaneous (accessible to all) publication of its price-sensitive information. Price-sensitive information should be made public in such a way that it is immediately available for everyone such that it is possible for investors to assess whether the information is complete, correct, and timely. The AFM is the authority for the supervision of the publication of price-sensitive information and will receive the press releases at the time of publication. The AFM does not review or approve the press releases before publication. The AFM does retrospectively evaluate whether investors have been accurately, timely, and completely informed.

Trading in securities using insider information damages the confidence in the proper working of the securities markets because the one who trades upon the basis of such information has an unjustified advantage over other investors. To guarantee the confidence of investors it is important to provide adequate regulation to prevent the use of insider information. Trading with the use of insider information is a serious offence and is prohibited for everyone. To this end, the AFM closely follows conduct and transactions in financial markets. If trading is determined to be in violation of the prohibition, a criminal or administrative sanction will follow. The prohibition is set down in Article 46(1) and (3) of the WTE. The prohibition is directed at everyone but recognizes a distinction between so-called "primary insiders" such as directors and member of the supervisory board of directors of an issuing institution and "secondary insiders" (everyone else).

Market manipulation is forbidden by Article 46b, paragraph 1 and consists of four sections. It is forbidden to (1) execute or bring about a transaction or place and order in securities by which an incorrect or misleading signal is relayed regarding the offer or bid price of the securities; (2) execute or bring about a transaction or place and order in securities in order to maintain the price of the securities at an artificial level; (3) execute or bring about a transaction or place and order in securities in which deception or misleading is made use of; and (4) spread information from which an incor- 
rect or misleading signal is relayed regarding the offer or bid price of the securities while the spreader knows or reasonably should know that the information is incorrect or misleading.

The scope of the prohibition against market manipulation is very broad. Manipulation is forbidden in or from the Netherlands. It is also forbidden to manipulate the market outside of Europe in securities, which are admitted to trading on a regulated market located or functioning in the Netherlands. It does not matter whether the transaction occurs via the system of a regulated market or outside of it.

The legislation includes the requirement for securities institutions to immediately report trading, which is reasonably suspicious of insider trading or market abuse to the AFM. This provision has a preventive character: if people are aware that "suspicious" transactions will be notified by those with the reporting obligation then this will have the potential effect of deterring people from performing such transactions. Additionally, such notifications support the supervisor in its supervision of market manipulation, which in turn contributes to the confidence of investors in the financial markets. The reporting duty applies only to securities institutions as defined in the WTE who have a reasonable suspicion that a transaction or an order, for which it in or from the Netherlands transacts, is in violation of the prohibition against insider trading or market manipulation. The securities institution does not have to prove that there actually was insider trading or market manipulation in order to make a notification. The reporting duty concerns license holders as well as those who are exempted from the licensing requirement. The reporting duty rests upon the institution itself. Within the institution, the reporting duty is directed at individuals who perform securities transactions as part of their employment.

\section{APPROACH}

We focus on changes in the information content of press releases by quoted companies before and after MAD. MAD could have led to a change in behaviour concerning the treatment of information by companies quoted on the stock exchange. Such possible changes allow us to investigate whether the information content of publications of price-sensitive information has changed since 1 October 2005. MAD is assumed to be an exogenous event with no changing behaviour prior to the switch. We need this assumption to carry out a statistical analysis in which MAD serves as a watershed. In the process of implementation markets were informed of its contents by consultation meetings with the regulator. This process took place during the spring and summer of 2005. An important aspect of our assumption is that we do not want anticipation effects to blur the analysis. It could be the case that firms already changed their behaviour prior to the implementation. Below, in Figure 1, we 


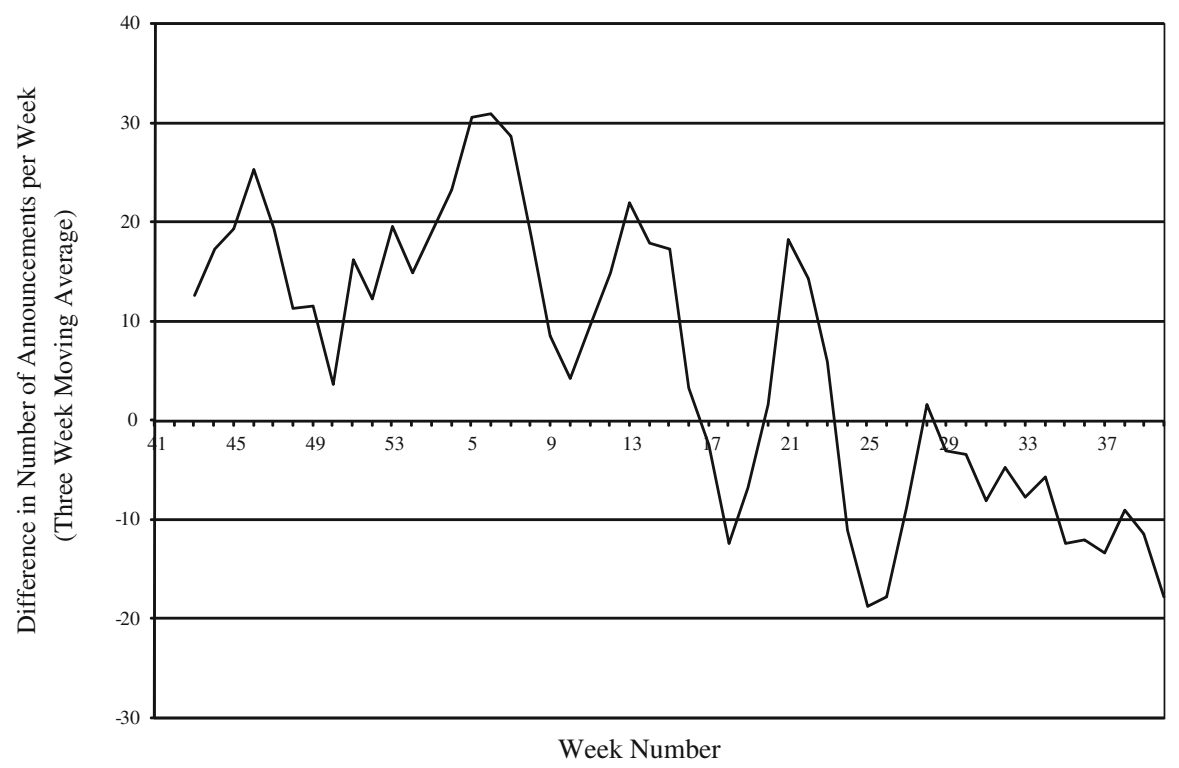

Figure 1 - Difference in weekly announcements before and after the market abuse directive

document that the number of press releases went up after the introduction of MAD but that this effect seems to fade away after about six months. Looking at the raw data we only observe a rise in the number of press releases after implementation and not an increase before MAD became effective.

Press releases contain information. This information is released because of the possibility that not all market parties have available valuable facts about issuing companies whose securities are admitted to trading on a regulated market in the Netherlands. In a clean market abnormal trading returns or volumes should not precede unexpected press releases. Other press releases, such as the upcoming publication of annual returns, might be subject to speculation in the market and show a pattern of abnormal returns in the period before its release, even in a clean market.

\subsection{Market model}

There are a number of approaches that can be applied to calculate returns: statistical and economic models. The statistical models are most widely used in the current event study literature, and they follow from statistical assumptions about the behaviour of stock market returns with hardly any dependence on economic arguments. The potential advantage from applying economic models is to be able to calculate the normal returns more precisely by adding economic restrictions. 
Two statistical models are the constant mean return model and the factor model (e.g., MacKinlay 1997). Using daily stock prices, the constant mean return model defines the expected return of a security to be the average of the daily returns over the estimation window. Factor models are applied to reduce the variance of the abnormal return by explaining more of the variance in the normal return. A commonly used factor model is the market model, which relates the return of a security to the return of its relevant market portfolio. The daily returns $R_{i, t}$ of an individual security $i$ on day $t$ are calculated as

$$
R_{i, t}=\frac{P_{i, t}-P_{i, t-1}}{P_{i, t-1}}
$$

where $P_{i, t}$ is the closing price for security $i$ on day $t$.

The market model is represented by

$$
R_{i, t}=\alpha_{i}+\beta_{i} R_{M, t}+\varepsilon_{i, t},
$$

where $R_{i, t}$ and $R_{M, t}$ are the period- $t$ returns of security $i$ and the market portfolio $M ; \alpha_{i}$ and $\beta_{i}$ are the market model parameters and $\varepsilon_{i, t}$ is the error term which has an expected value of zero. The market model is a one-factor model, whereas other factor models may use multiple factors to further reduce variation in the normal returns. One such example is the use of industry indexes in addition to the market index.

To improve the fit of the normal return equation, we use the return of the relevant capitalization index as the relevant market portfolio, rather than the index for the entire Amsterdam stock exchange. This means our market model for normal returns is represented by

$$
R_{i, t}=\alpha_{i}+\beta_{i} R_{C, t}+\varepsilon_{i, t},
$$

where $R_{i, t}$ is the return on security $i$ for at time $t$ and $R_{C, t}$ is the return on the relevant capitalization index $C$ at time $t$. The expected normal return is estimated over a given estimation window for each announcement separately, meaning that $\alpha$ and $\beta$ are estimated for each news announcement. Announcements are considered firm specific, so each announcement is associated with the returns of the security that released it. The estimated abnormal return is then:

$$
A R_{j, t}=R_{j, t}-\left(\hat{\alpha}_{j}+\hat{\beta}_{j} R_{C, t}\right),
$$

where $A R_{j, t}$ is the abnormal return for announcement $j$ at time $t$, where the returns are those of the security releasing announcement $j$. Thus, $\hat{\alpha}_{j}$ and $\hat{\beta}_{j}$ are the estimates of the market model parameters for announcement $j$. Time $t$ is here relative to the date of the news announcement, with $t=0$ being the announcement day. 
To derive conclusions about the effects of certain events, the abnormal returns must be aggregated. This aggregation has to occur along two dimensions. Firstly, across time to compute cumulative abnormal returns to make a judgement about possible insider trading within a given time period and secondly, across securities to make a judgment about a change in investor behaviour in the market as a whole. For each announcement the cumulative abnormal return $(C A R)$ is then calculated by summing up the abnormal returns for the period of interest:

$$
C A R_{j}(a, b)=\sum_{t=a}^{b} A R_{j, t} .
$$

To investigate the effect of the change in market abuse regulation market wide, the $C A R$ s of the separate announcements are then averaged to get the cumulative average abnormal return $(C A A R)$ :

$$
C A A R(a, b)=\frac{1}{N} \sum_{j=1}^{N} C A R_{j}(a, b),
$$

where $a$ and $b$ are the start and the end of the period over which the preannouncement stock market behaviour is to be evaluated.

Once this aggregation has taken place, a single measure for the cumulative average abnormal return $(C A A R)$ over the period of interest remains, for which the significance can be tested using the t-statistic

$$
t_{C A A R}=\frac{C A A R(a, b)}{\operatorname{var}(C A A R(a, b)) 1_{1 / 2}} \sim N(0,1),
$$

where $a$ and $b$ are the start and the end of the period over which the preannouncement stock market behaviour has to be evaluated.

The reaction of volumes around the release of a news announcement is estimated along similar lines. Wong (2002) and Monteiro et al. (2007) extensively describe how normal volumes and thus abnormal volumes have to be calculated. The main differences are adjustments for first order serial correlation and day-of-the-week effects, after which volume can be assumed to be approximately normally distributed, which allows for the same significance test as is applied to the abnormal returns. Day-of-the-week dummies are incorporated in the model due to the anomaly documented in the literature that stock market volume is dependent on the day of the week (e.g., Berument et al. 2004; Berument and Kiymaz 2001; Kiymaz and Berument 2003). So, first the natural logarithm is taken of the volume traded on day $t$, and regressors are included to control for weekdays. Expected volume is then estimated for each announcement, which gives the abnormal volume $(A V)$. 
The cumulative abnormal volume is then calculated for each announcement by summing up average volumes for the period of interest. This leads to similar equations as documented for returns.

The increase in the cumulative average abnormal return and cumulative average abnormal volumes prior to the announcement date are common instruments to measure the extent of information leakage and illegal insider trading. This leads to the first hypothesis, which will be tested in this paper:

Hypothesis 1 The absolute cumulative average abnormal return/volume prior to corporate news announcements is smaller after the implementation of MAD.

MAD may also lead firms to release information to the public, which they would not release without it. This is a desired result if this information is price relevant, which decreases the information asymmetry in the market and gives investors more equal opportunities on the stock market. Tighter rules and regulations might on the other hand be termed as 'regulatory overkill' (e.g., Kabir and Vermaelen 1996). The new regulation might lead firms to publish all information, including information, which is not price relevant. In this case, investors might be overloaded with information, making the market less efficient. If firms indeed publish less informative announcements, the average price and volume reaction after the announcement date will be lower. This leads to the second hypothesis that will be investigated in this paper:

Hypothesis 2 The absolute average abnormal return/volume after corporate news announcements is smaller after the implementation of MAD.

\subsection{Estimation and event window}

For the model to have predictive power, $\alpha$ and $\beta$ have to be estimated using a sufficiently large number of days. There is a payoff between adding predictive power and losing data. The larger the estimation window, the more news announcements will not be able to be used because not enough data for the securities is available. On the other hand, if the estimation window is too small, there is not much predictive power in the model. The choice of the length of the estimation window used in the event study literature covers a range of approaches. Observed lengths are 240 trading days (Brown and Warner 1985; Monteiro et al. 2007), 150 trading days (Meulbroek 1992; Sanders and Zdanowicz 1992), and 100 trading days (Kabir and Vermaelen 1996; Keown and Pinkerton 1981). We use an estimation window of 120 trading days. This length of the estimation window is also used by Wong (2002) and proposed by MacKinlay (1997).

A second issue is the timing of the estimation window. This timing depends on the decision as to what confines the event window. Sanders and Zdanowicz (1992) note that pre-announcement average abnormal returns are measured 
over time periods varying from 10 to 60 days. Which period is considered to be likely to be influenced by information leakage and illegal insider trading influences the period that should be used to estimate the market model parameters. Similar to Keown and Pinkerton (1981) - who base their choice to exclude the 25 trading days preceding the news announcement on results of Halpern (1973) - the impact of the market reaction to the announcement on the market model parameters is taken into account by excluding the 30 trading days prior to the press release. Thus, the analyses are based on a model for which the parameters have been estimated using an estimation window of 120 trading days, from $t=-150$ to and including $t=-30$, where $t=0$ is the day of the news announcement.

After establishing the extent to which prices and volumes react abnormally relative to the market around the publication of a news announcement, it is important to determine the timing of this reaction and whether the change in regulation as of 1 October 2005 alters this timing. As Keown and Pinkerton (1981) point out, Halpern (1973) finds that $58 \%$ of the price movement occurs one month prior to the announcement date. We evaluate the absolute $C A A R$ and the $C A A V$ over the period $t=-30$ to $t=-1$, where $t=0$ is the day of the announcement. In sum, (ab)normal returns are estimated using an estimation window of 120 trading days, starting 30 trading days prior to the release of the announcement. The 30 days preceding the announcement are then our event window, over which we investigate the abnormal price movements. ${ }^{1}$

\subsection{Bad news and good news}

A contribution of this paper to the existing literature is to provide insights in the difference in price and volume reaction between bad news announcements and good news announcements.

The difficulty here lies in the decision how to make the distinction between these two categories. Wong (2002) distinguishes bad news from good news by the sign of the return after a news announcement. There are two problems with this definition: illegal insider trading and market anticipation. If illegal insider trading is a relevant problem, the information within the announcement is already - at least partially - digested by the market prior to its official release. This takes place because insiders in possession of this information use their knowledge and trade on it prior to it being released to the market. The market also recognizes this informed trading and follows these

1 Halpern (1973) finds that as much as half of the price movement occurs two months prior to the announcement date. Although the period prior to 30 days before the announcement date is included in the regression analysis as part of estimation window, a second measure is the absolute $C A A R$ and the $C A A V$ for the 60-day pre-announcement period from $t=-60$ to $t=$ -1 . The results using this 60 -day pre-announcement period are generally similar to those looking at the 30-day pre-announcement period, and are available from the authors upon request. 
movements (Meulbroek 1992). In addition to recognition of informed trading, the market may anticipate certain announcements. For these reasons, the price change after an announcement might lead to misspecification of an announcement in terms of it being bad or good news. Therefore the distinction between bad and good news announcements is made by looking at the price change around the date of the announcement. An announcement is defined as good news if the cumulative abnormal return of the period $t=-5$ up to and including $t=4$ is larger or equal to zero. In the case this $C A R$ is negative, the announcement is considered bad news. Using Wong's (2002) definition of good and bad news does not alter the main conclusions; the results of using this approach are available upon request.

\section{DATA AND DESCRIPTIVE STATISTICS}

This section introduces the data we use for the empirical analysis and presents the most salient statistics. In Appendix I and II more detailed information about the data can be found.

\subsection{Data}

This paper applies an event study approach to the effects of the change in market abuse regulation on 1 October 2005. Thus this date - the event date forms the midpoint of the period to be investigated. New regulation regarding market abuse and market manipulation most recently became effective on 1 January 2007. To prevent the results of the analyses in this paper to be affected by this new set of rules and regulations, the post-event period ends on 31 December 2006. To make the pre-event period comparable to the postevent period, the same length of time is used for both periods, meaning this study is based on data from 15 months prior to the change in legislation and 15 months after the change.

Corporate news announcements for the period from 1 July 2004 to 31 December 2006 for listings on the Amsterdam Stock Exchange are collected from the publicly accessible online corporate news database of NYSE Euronext. Given that this paper also wishes to evaluate the changes in market behaviour by firm size, announcements are collected by NYSE Euronext's compartment division: compartment A (Large Caps, 5,398 announcements), compartment B (Mid Caps, 2,736 announcements), and compartment C (Small Caps, 2,171 announcements). All announcements published after 5pm are considered as announcements published on the next trading day.

Daily closing prices and trading volumes for the securities releasing news announcements are collected using Thomson One. The daily closing prices for the cap and industry indices used to obtain the abnormal returns are also obtained from Thomson One. All non-trading days are removed from 
the data. Then, for every security, all days for which no return can be calculated are removed. The next step is to remove those announcements for which too little data is available. For the abnormal returns analysis daily returns are needed for the period from 150 days prior to the announcement to 30 days prior to the announcement. All announcements for which there are less than 120 observed returns in this period are eliminated from the dataset. After this selection process 5,168 announcements remain, of which 2,747 by large capitalization firms, 1,749 by mid cap firms, and 672 by small cap firms. Since extreme values and outliers may heavily influence the results of the analysis, the dataset is further cleaned. All announcements by the IT service group Getronics are removed, since the results for Getronics are heavily influenced by a stock split in May 2005. As a last step, all announcements with an abnormal return in the period $t=-60$ to $t=5$ larger than or equal to $20 \%$ are removed from the dataset, resulting in the final dataset of 4,979 announcements.

The problem with estimating abnormal volumes is that for the indices volumes are not recorded. Therefore, volume indices have to be constructed. Since the analysis uses cap size as a group-defining characteristic, three volume indices are created: large cap volume, mid cap volume, and small cap volume. The approach here is to simply add the daily volumes of large cap securities for each calendar date, resulting in a measure for daily market volume for large caps. The same process is used to create a mid cap and a small cap market volume measure. In doing so, only the securities remaining in the final dataset are considered. Furthermore, since firms do not remain unchanged in terms of cap size, the decision needs to be made in which market volume index a security should be included. The criterion used here is to include the daily volume of a security in the index if the share of the total amount of announcements published by a firm between 1 July 2004 and 31 December 2006 within the relevant cap size is larger than $95 \%$.

\subsection{Descriptive statistics}

The final dataset contains 4,979 announcements released by 124 securities over the period from 1 July 2004 to 31 December 2006. Table 1 shows the composition of this dataset by cap size (large, mid and small) and period (before or after MAD). A Pearson's chi-square test for independence, with a p-value smaller than 0.01 , does not allow the hypothesis of no relationship to be rejected. This indicates that there is a relationship between the period and the number of corporate news announcements released by the different capitalization groups. Where prior to MAD the large caps account for $51 \%$ of all announcements, this percentage is $57 \%$ afterwards. Besides the change in the distribution of total announcements by cap size, it is also clear that after MAD came into effect a larger number of announcements have been pub- 
TABLE 1 - ANNOUNCEMENTS BY CAPITALIZATION AND SUPERVISOR

\begin{tabular}{|c|c|c|c|}
\hline \multirow[t]{2}{*}{ Capitalization } & \multicolumn{2}{|c|}{ Market Abuse Directive } & \multirow[t]{2}{*}{ Total } \\
\hline & Before & After & \\
\hline Large & 1,078 & 1,633 & 2,711 \\
\hline Mid & 769 & 881 & 1,650 \\
\hline Small & 257 & 361 & 618 \\
\hline Total & 2,104 & 2,875 & 4,979 \\
\hline
\end{tabular}

lished period $(2,875$ vs. 2,104$)$. This also holds for the three cap size groups separately.

A similar observation has already been documented by the AFM (2007) in a report that looks at the period of one year after the regulatory change. In a comparison of the number of announcements per month, the report shows that in the first months following the introduction of MAD the number of press releases is larger than in the same month the year before.

Figure 1 depicts a similar trend looking at announcements published per calendar week. The first of October 2005 is a Saturday, with Monday 3 October 2005 being the start of week 41 of the year 2005, which is the first week the MAD was in effect. The number of announcements in this week is compared to the number of announcements in week 41 of 2004. Such a comparison is made for all weeks up to comparing week 40 of 2006 to week 40 of 2005. To smooth out the volatility in weekly announcements, the numbers have been averaged over three weeks. Figure 1 depicts the difference in the three-week moving averages of the post- and pre-MAD period. Figure 1 shows that the number of announcements published in each week are higher after MAD comes into effect. This difference is largest in the first weeks and months after the introduction of MAD. The difference only drops below zero after week 17, which is the average number of announcements for the weeks 15, 16, and 17 of 2006 minus the average number of announcements for the weeks 15, 16, and 17 of 2005. Similar to the conclusions in the report by the AFM (2007), firms publish more announcements up to half a year after MAD becomes effective.

To investigate whether the increase in total number of announcements can be said to be a result of the change in the market abuse regulation, a similar overview to Table 1 - at the level of single securities - is given in Table 12 in Appendix I. Performing a paired sample $t$-test on those securities that have a positive number of announcements in both supervisor periods yields an untabulated mean increase of 3.05 in the number of announcements posted by a 
TABLE 2 - ANNOUNCEMENTS BY ANNOUNCEMENT TYPE AND SUPERVISOR

\begin{tabular}{lrrr}
\hline Announcement type & \multicolumn{2}{c}{ Market } & Abuse Directive \\
\cline { 2 - 3 } & Before & After & \\
\hline Alliances/M\&A & 227 & 574 & 801 \\
Sales & 97 & 99 & 196 \\
Share introduction and issues & 17 & 483 & 500 \\
Commercial operation & 125 & 108 & 233 \\
Income & 740 & 777 & 1,517 \\
Corporate life & 21 & 161 & 182 \\
Board/general meeting & 117 & 78 & 195 \\
Meetings/events & 21 & 26 & 47 \\
Other & 739 & 569 & 1,308 \\
Total & 2,104 & 2,875 & 4,979 \\
\hline
\end{tabular}

single security during the 15 months after MAD, compared to the 15 months prior to MAD. This difference is significant at the 5\% level. If the amount of news related to a firm that influences stock prices is assumed to be constant over time, at least over the total sample of securities, this difference supports the suspicion that firms release more announcements probably in fear of sanctions after MAD, regardless of the news announcements containing relevant information or not. Table 13 in Appendix I documents which companies are included in which index.

In the literature on insider trading and insider trading laws, different types of corporate announcements are used to investigate the extent of illegal insider trading. Announcements in the database of company news are divided into a number of topics. Most announcements are classified by several topics. All combinations of topics are subdivided into nine different announcement categories. Table 2 denotes the number of announcements within each category, in total and before and after MAD. Performing Pearson's chi-square test of independence indicates that the share of total announcements of a certain announcement type is not independent of the change in regulation. The null hypothesis of no association between announcement type and regulation is rejected at the 1\% level. Table 14 in Appendix II shows a detailed overview of the categorisation of news types.

With the dependence between periods and cap size on the one hand and between period and announcement type on the other hand, it is appropriate to divide the dataset along these dimensions and to perform the analyses separately for the three cap sizes and the different announcement types. As noted above, another dimension that might influence the results of the analyses is 
TABLE 3 - ANNOUNCEMENTS BY WEEKDAY AND SUPERVISOR

\begin{tabular}{|c|c|c|c|}
\hline \multirow[t]{2}{*}{ Weekday } & \multicolumn{2}{|c|}{ Market Abuse Directive } & \multirow[t]{2}{*}{ Total } \\
\hline & Before & After & \\
\hline Monday & 348 & 505 & 853 \\
\hline Tuesday & 396 & 544 & 940 \\
\hline Wednesday & 451 & 641 & 1,092 \\
\hline Thursday & 471 & 620 & 1,091 \\
\hline Friday & 438 & 565 & 1,003 \\
\hline Total & 2,104 & 2,875 & 4,979 \\
\hline
\end{tabular}

the day of the week an announcement is published. Table 3 reports the number of announcements by weekday and by period. The value of a Pearson's chi-square test is 2.35 , which is associated with a probability of 0.67 . Thus the hypothesis of independence between supervisor and number of announcements by weekday cannot be rejected and it is therefore not necessary to take account of the weekday an announcement is released on, when evaluating the effects of MAD.

\section{RESULTS}

This section presents the results of the effectiveness of MAD. It first shows an analysis of abnormal returns and volumes. Thereafter results by type of announcement and industry are shown.

\subsection{Abnormal returns}

The development of abnormal returns is plotted in Figure 2. Plot A shows that the trend in the CAAR for good news announcements is similar under both regimes, whereas the CAAR for bad news announcements before MAD falls below that of the post-implementation period as early as 12 days prior to the announcement. Looking at firm size, Plot B for the large caps shows contradicting trends. For good news announcements it seems that the $C A A R$ for AFM is higher than that for Euronext, yet the absolute CAAR for bad news announcements is smaller for AFM than for Euronext. The opposite picture is shown in Plot $\mathrm{C}$ for the mid caps. The difference in the development of the $C A A R$ prior to the announcement date is in line with a cleaner market after MAD for good news announcements, yet contradicting it for bad news announcements.

The most pronounced differences between the two regimes in terms of pre-announcement CAAR trends are visible in Plot D for announcements by 
(a)

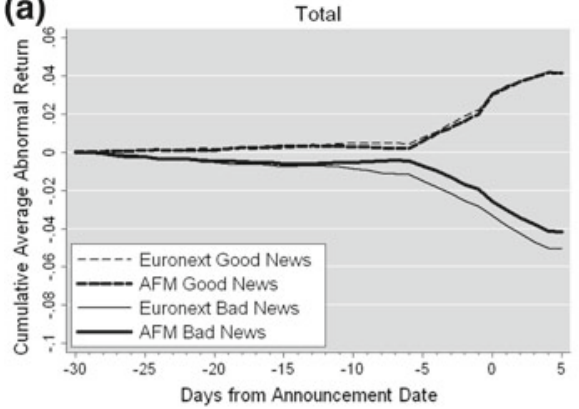

(c)

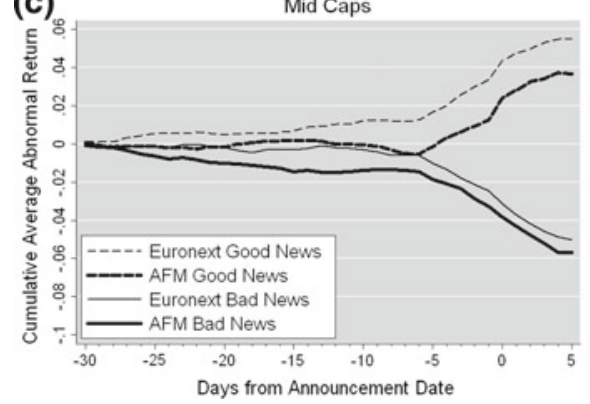

(b)

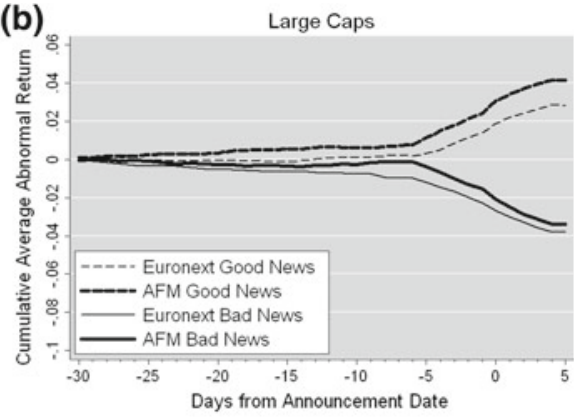

(d)

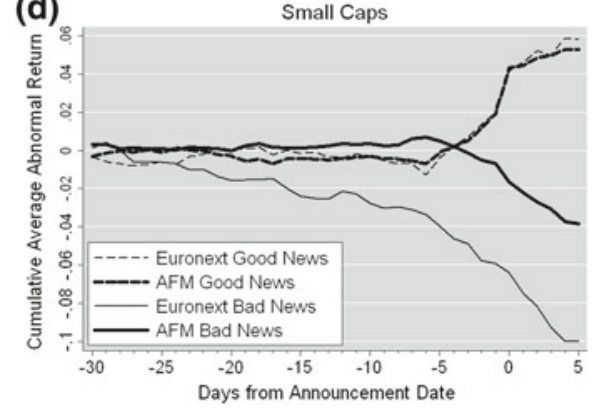

Figure 2 - Plots of cumulative average abnormal returns

small firms. There is no difference between the two regimes looking at the plots for good news announcements, with both CAARs fluctuating around zero until 5 days prior to the announcement date. However, the absolute average abnormal returns for bad news announcements are much larger under Euronext than under AFM. The CAAR for AFM remains around zero until $t=-5$, whereas the plot for Euronext drops below that for AFM as early as 28 days prior to the press release, with the difference increasing.

Table 4 gives the statistics related to Figure 2 and reports the cumulative average abnormal returns $(C A A R \mathrm{~s})$ for various sub-samples of the data for several periods around the publication of the announcement. "30-day runup" is the CAAR for the 30-day period preceding the announcement (from $t=-30$ to $t=-1$ ). Similarly, "5-day run-up" is the CAAR for the 5-day preannouncement period from $t=-5$ to $t=-1$. "day 0 aar" is the average abnormal return on the day of the announcement $(t=0)$. Finally, "5-day post caar" is the $C A A R$ for the 5 days after the announcement $(t=0$ to $t=4)$. The means and differences are given for the entire sample (Total) as well as for the announcements categorized by firm size (Large caps, Mid caps, Small caps). Panel A contains the results for announcements considered to be bad news, 
whereas Panel B contains the results for good news announcements. The standard errors are reported under SE.

Looking at the total sample, for both good and bad news announcements, the run-up $C A A R$ is significant for both pre-announcement periods (5-day and 30-day run-up), both before and after MAD. For good news announcements, the difference between the CAARs of the two regimes is not significantly different from zero. However, for bad news announcements the absolute $C A A R$ is significantly larger before MAD for the 30 -day run-up. This indicates that MAD has led to a more efficient market.

Looking at firm size, the results for large capitalization firms are ambiguous. For bad news announcements the absolute pre-announcement CAAR is larger before MAD, whereas for good news announcements, the 30-day run-up is significantly larger after MAD, which in turn would indicate a less efficient market. For mid caps, the differences are insignificant for bad news announcements, whereas they are significant (and have the expected sign) for good news announcements. The results for small capitalization firms (Small caps) are in line with those for the entire sample. There is no significant difference between the CAAR of both regimes for good news announcements, yet for bad news announcements, the absolute pre-announcement $C A A R$ before MAD is significantly larger than afterwards. Comparing the statistically insignificant mean 30-day run-up CAR of $-0.67 \%$ after MAD with the highly significant $-5.93 \%$ before MAD, the hypothesis that the CAAR is smaller after MAD cannot be rejected (with the difference of $-5.26 \%$ being significant at the $1 \%$ level).

In sum, for large caps and mid caps there is no clear-cut change in the pre-announcement $C A A R$ after MAD. Nevertheless, MAD has had an effect on the abnormal returns prior to press releases of the small caps. The preannouncement run-up for bad news announcements has decreased and is no longer significantly different from zero, suggesting a change in market behaviour, and providing support for Hypothesis 1.

Looking at the effect of the change in the market abuse regulation on the news value of announcements, the average abnormal return on the announcement day can be used as a proxy for the information content of the announcement. The results in Table 4 show that differences in the day zero average abnormal returns are insignificant. If anything, the results seems to provide support for a hypothesis that announcements are more informative after MAD, since seven out of eight differences in the absolute announcement day $A A R$ are negative. Hypothesis 2 is thus rejected.

\subsection{Abnormal volumes}

Even though price reactions provide important insights in the effects of the release of new information around the date of the announcement, trading on 
THE EFFECTS OF A CHANGE IN MARKET ABUSE REGULATION

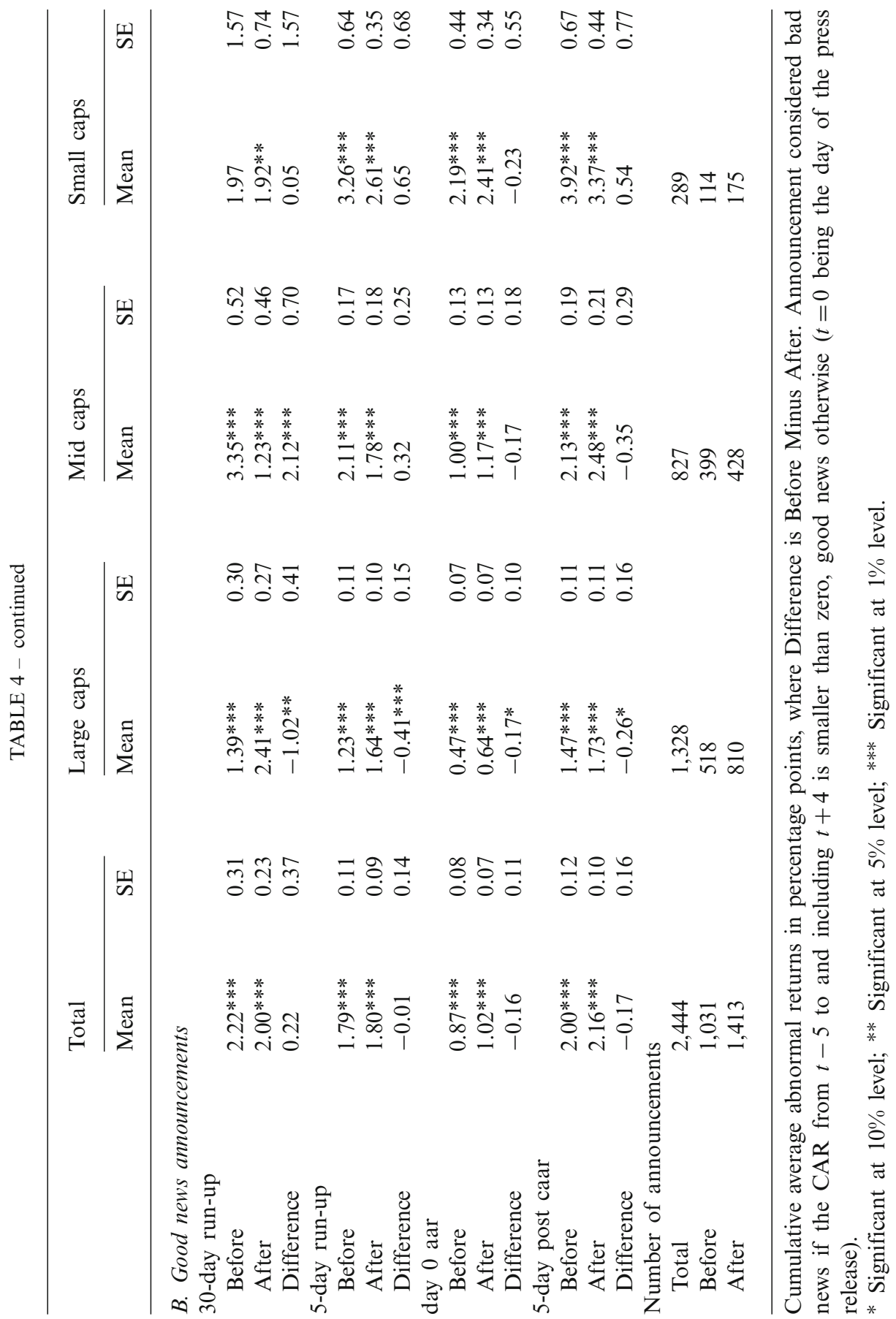



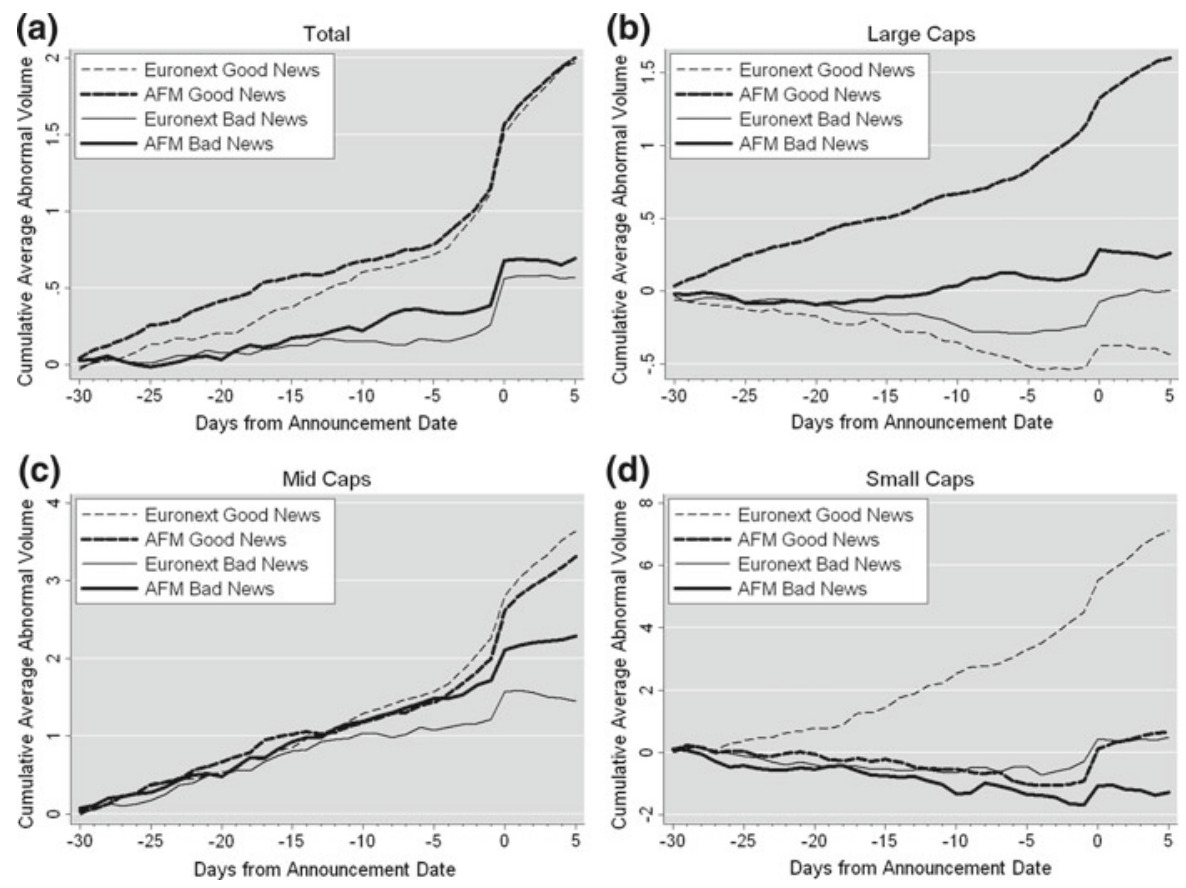

Figure 3 - Plots of cumulative average abnormal volumes

share relevant information might not be seen in price changes if the information is not public. If an individual possesses information which leads him/her to believe a certain stock price is going to rise in the near future, and if the information is not known to or anticipated by the market as a whole, the transaction will not necessarily lead to an increase in the price of the stock. Insider trading might then only be discovered when examining trade volumes.

Figure 3 and Table 5 show the results of the abnormal volumes analysis. The plots of the $C A A V_{\mathrm{s}}$ in Figure 3 show developments similar to those observed in Figure 2 for the $C A A R$ s. All announcements taken together, there is a clear jump in the $C A A V$ on the day of the announcement, which indicates that the announcements have real news value. For the total sample (Panel A), for bad news, the run-up in the $C A A V$ is rather small when compared to the run-up in the $C A A V$ for good news announcements, which is in line with Wong's (2002) hypothesis that good news disseminates faster than bad news. Panel D for the small caps sample shows that the CAAV for bad news announcements moves around zero until the announcement day, when a clear upward jump is visible. For good news announcements before MAD, the same trend as for the total sample is observed: a steadily increasing $C A A V$ prior to the news announcement. 
THE EFFECTS OF A CHANGE IN MARKET ABUSE REGULATION

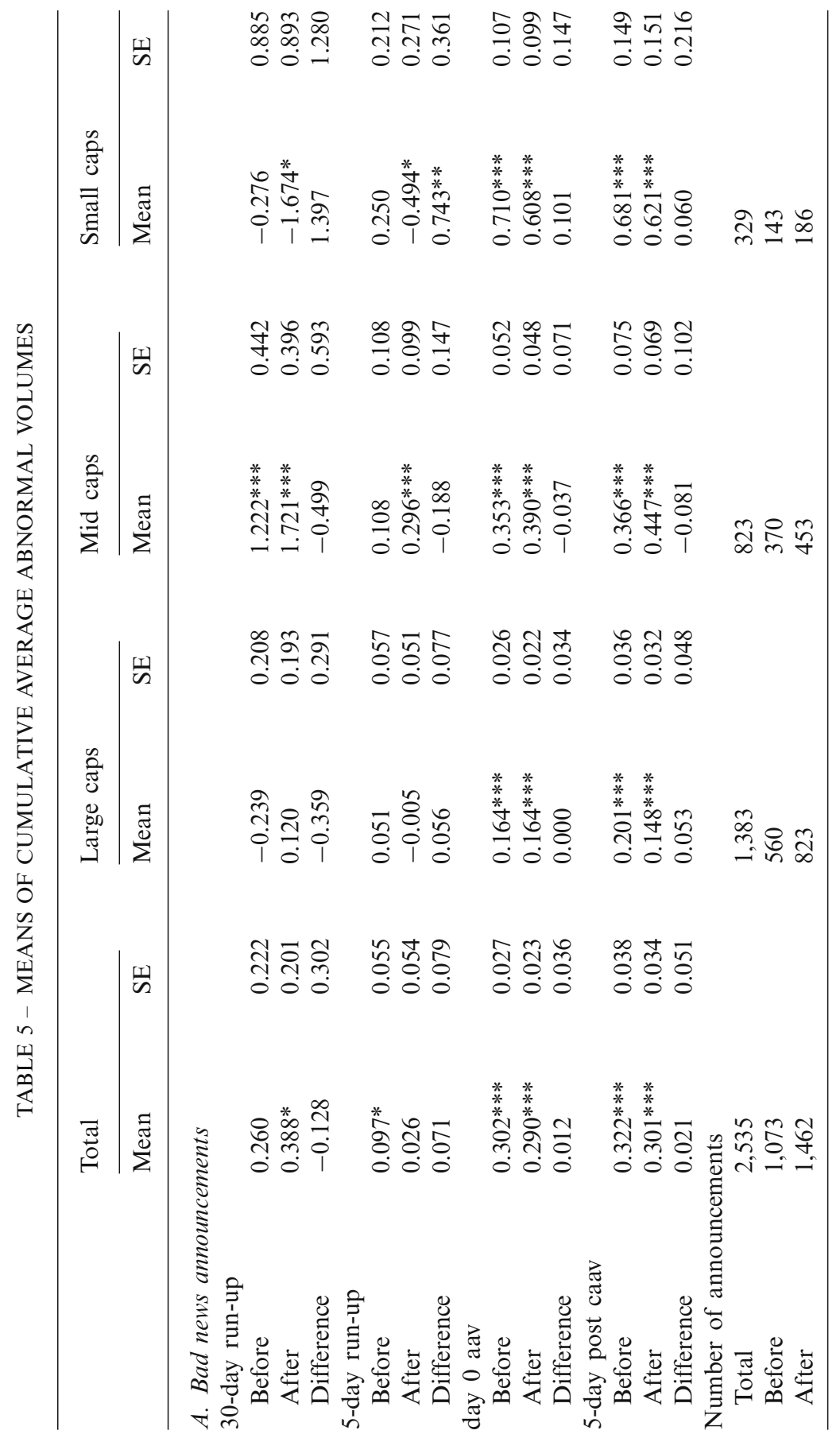


TYAS PREVOO AND BAS TER WEEL

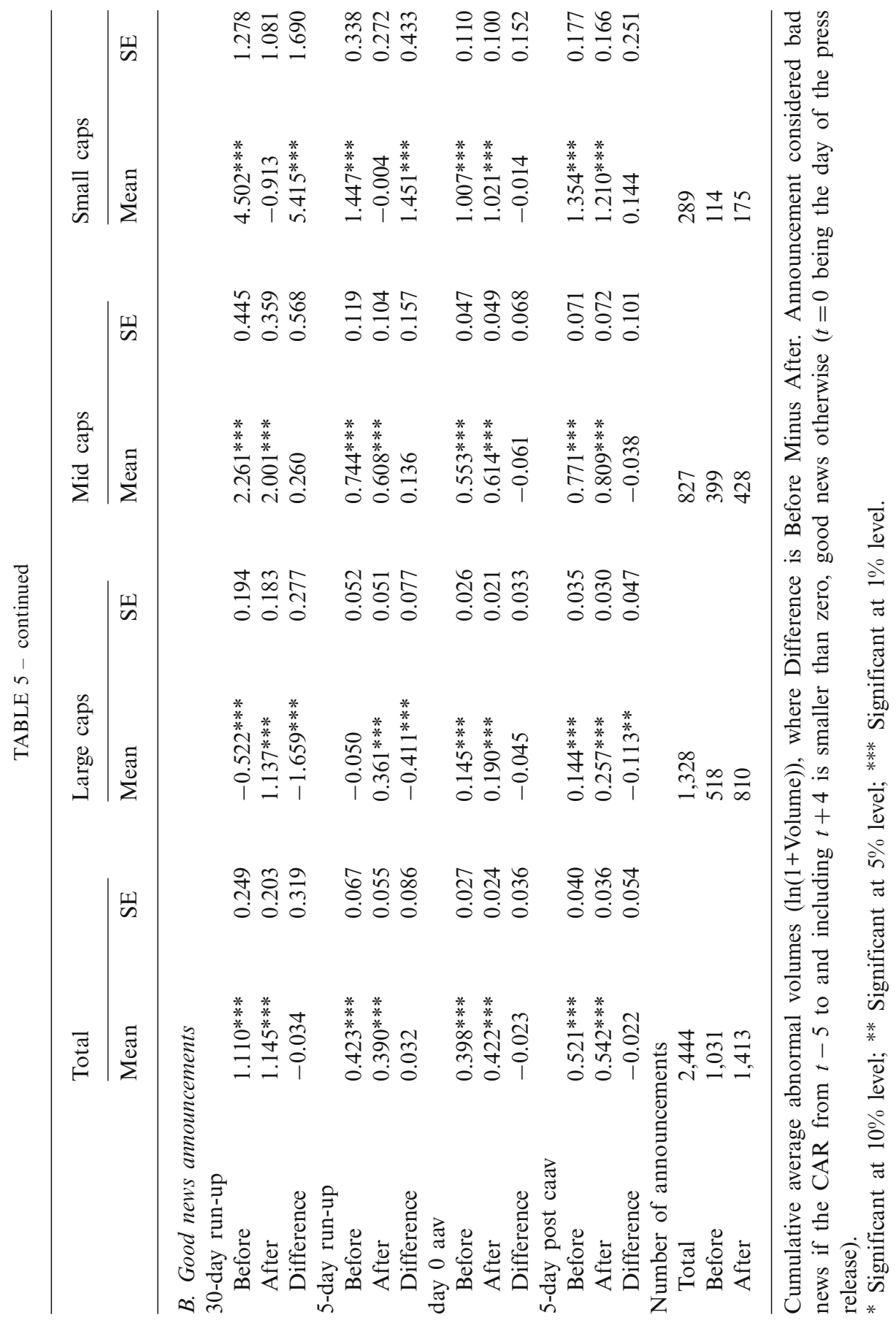


Where there seems to be no clear change in the reaction of the stock market in terms of volume after MAD for the total sample and the mid cap sample, the effects for the large cap sample are not as expected. For good news announcements before MAD, a large drop in the $C A A V$ is visible, whereas under AFM supervision the $C A A V$ shows a strong increase long before the announcement day. This would indicate that in terms of volumes, the market for large caps has become less clean after MAD.

When turning to the results for the mid caps, a strong increase in volumes is visible prior to the release of the news announcement. The trend in the $C A A V \mathrm{~s}$ for mid caps have not changed after the MAD came into effect, yet the large run-up prior to the announcement date for good news in the small caps sample has disappeared after MAD. This result strengthens the results from the abnormal returns analysis and provides additional support for smaller abnormal volumes after 1 October 2005.

The conclusions drawn from the plots in Figure 3 are confirmed by the statistics in Table 5. For bad news, the run-up in the 30-day pre-announcement period is significant at the $5 \%$ level only for the mid caps sample, with the difference between the two regimes being insignificant. For good news, the 30day run-up is positive and significant for all samples except for the small caps sample after MAD, where the $C A A V$ is not significantly different from zero. The $A A V \mathrm{~s}$ on the announcement day are all positive and significant at the $1 \%$ level, whereas there are no significant changes in these day-zero $A A V \mathrm{~s}$ after the transfer of supervision on 1 October 2005.

Although the results presented in Table 5 are in line with those of the abnormal returns analysis presented in Table 4, the volume index measures used in calculating the abnormal volumes around corporate news announcements may have influenced them. Since the measure for the market volume is self-constructed using the securities in the dataset, the results may be sensitive to changes in this measure.

These results for the abnormal volumes analysis confirm those from the abnormal returns analysis. The effect of MAD is most pronounced for small cap firms. There are strong indications that for those firms, the increase in the $C A A R$ and $C A A V$ prior to the public release of an announcement has disappeared. In the case of small firms, there is strong support for Hypothesis 1, suggesting a cleaner and more efficient market. The results of both the abnormal returns and abnormal volumes analyses provide no support for Hypothesis 2, leading to the conclusion that there are no significant changes in the information content of news announcements.

\subsection{Type of announcement}

There are numerous studies on the prevalence of illegal insider trading. The analyses are based on stock market behaviour surrounding news announce- 

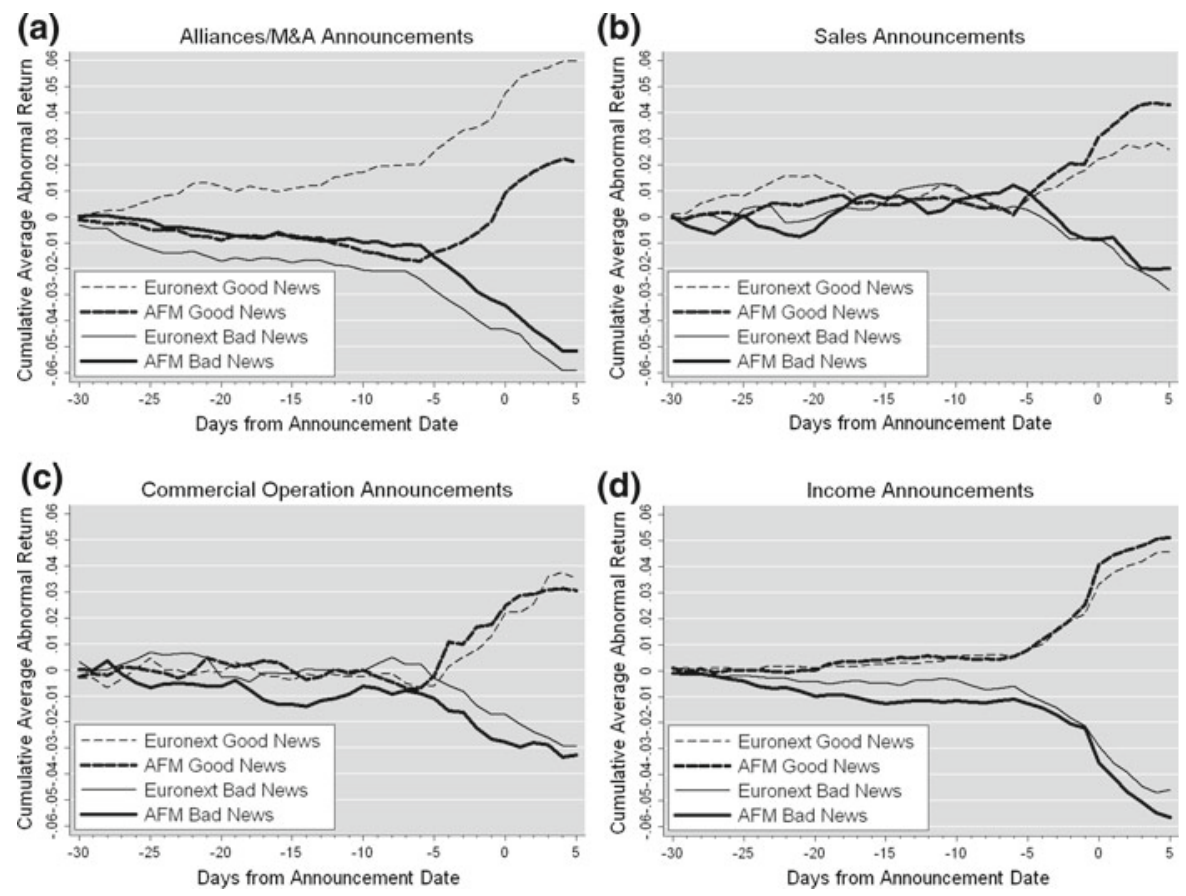

Figure 4 - Plots of cumulative average abnormal returns: by announcement type

ments released by firms. The type of news announcement used to analyse the extent of illegal insider trading differs across studies. To investigate the different effects for different types of announcements, Figure 4 and Table 6 report the results for Alliances/M\&A announcements, Sales announcements, Commercial Operation announcements and Income announcements.

Panels B, C and D of Figure 4 show no apparent effects of the change in market abuse regulation for sales announcements, commercial operation announcements or income announcements. The $C A A R \mathrm{~s}$ before and after MAD follow the same trends. So for these announcement types, there is no indication that MAD altered the market's behaviour. The picture for announcements concerning alliances and mergers and acquisitions (Panel A) leads to a different conclusion.

For Alliances/M\&A announcements the plots in Panel A of Figure 4 show that the price reaction to good news before MAD is apparent long before the official announcement at day $t=0$. This run-up suggests leakage of information and illegal insider trading and is consistent with the literature documenting stock market behaviour surrounding M\&A announcements (see e.g., Keown and Pinkerton 1981; Meulbroek 1992). This run-up is no longer visible 


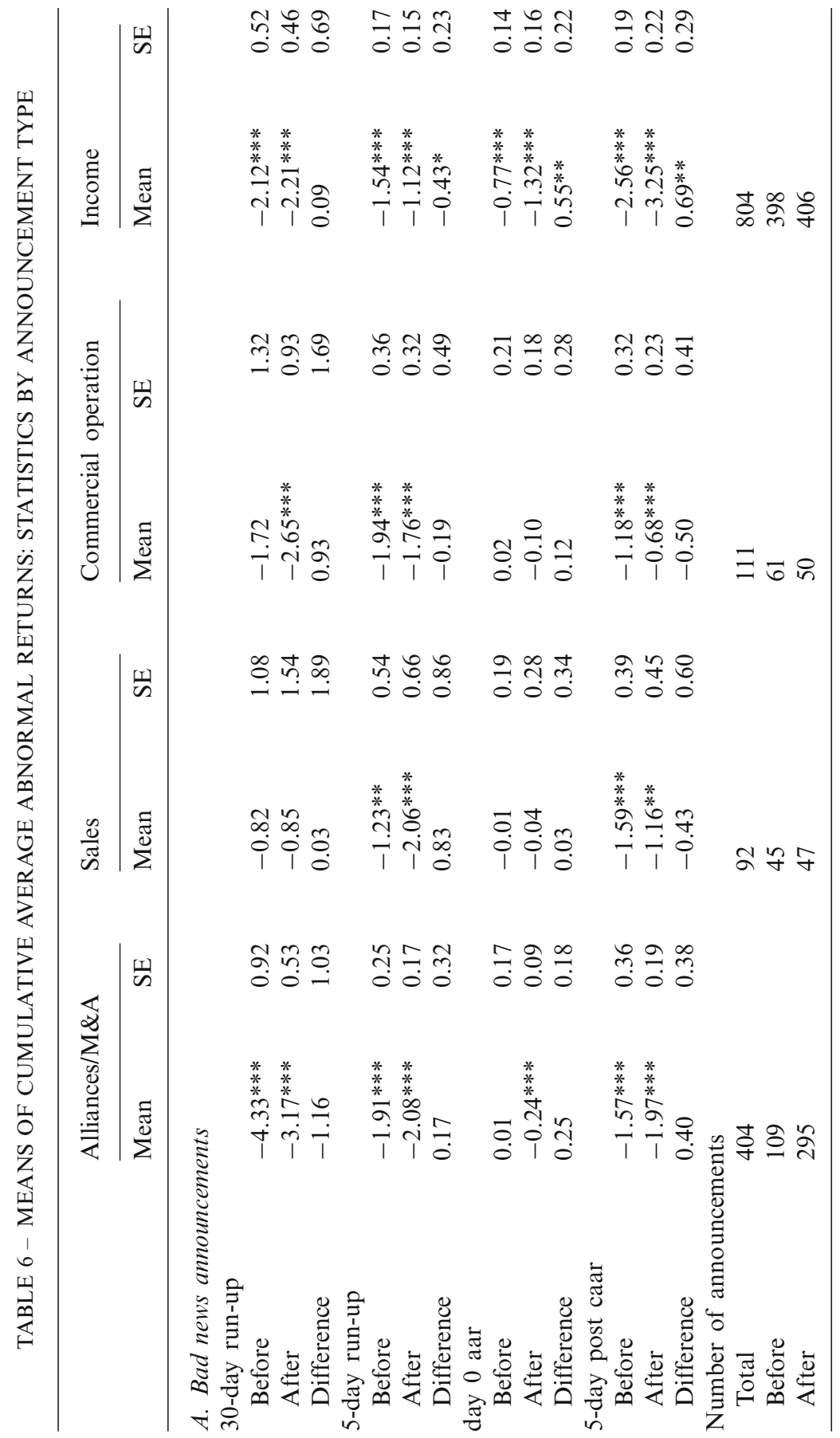


TYAS PREVOO AND BAS TER WEEL

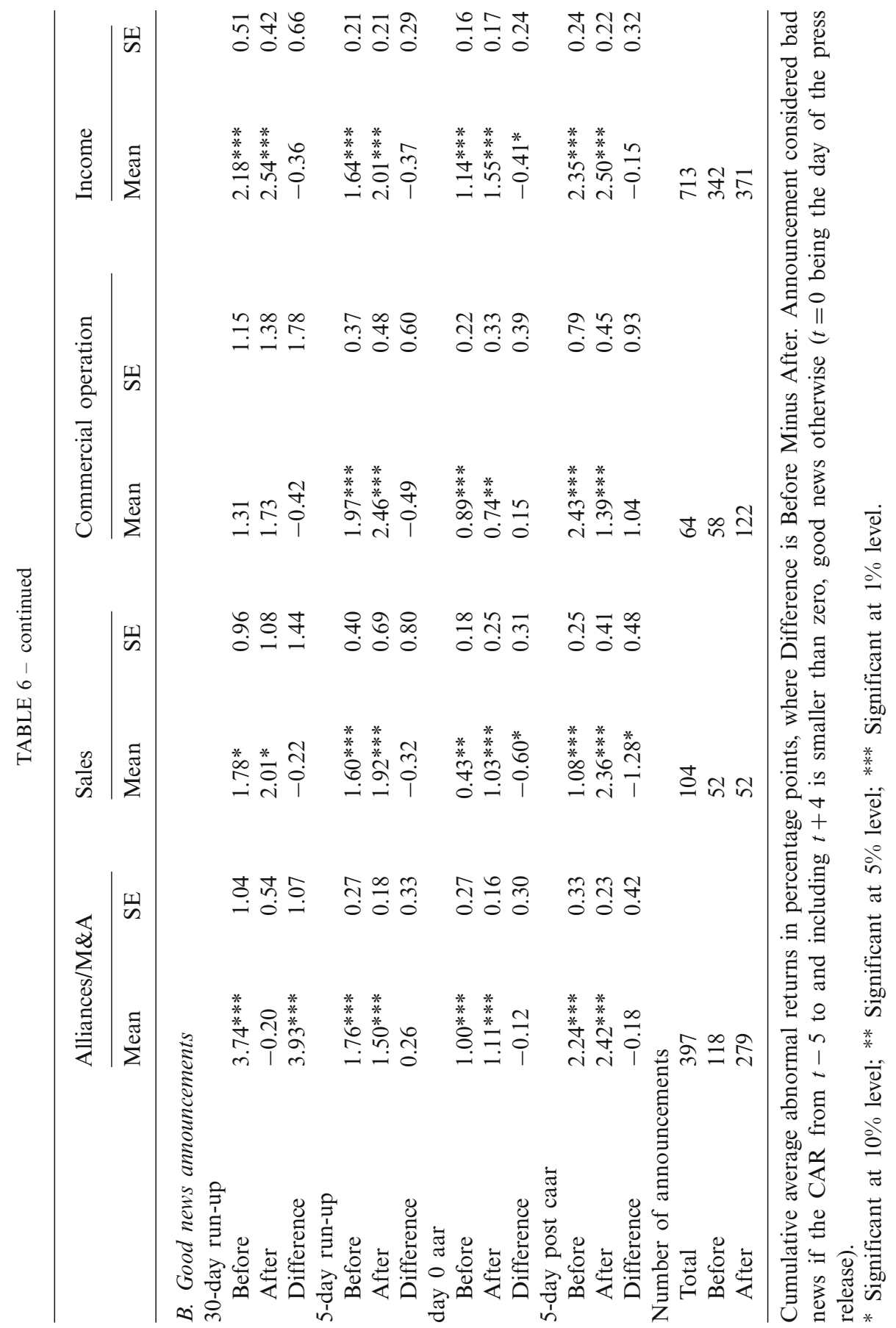


after MAD, which means the results for Alliances/M\&A Announcements lend support for Hypothesis 1, consistent with a cleaner market after MAD.

The results shown in Table 6 confirm these observations, with the 30-day run-up for bad news Alliances/M\&A announcements being insignificant after MAD, whereas it is positive and significant before. Having a closer look at the $A A R$ s on the day of the announcement, the day zero absolute average abnormal returns are significantly larger after MAD for income announcements and for sales announcements containing good news, meaning these events contain more information than similar announcements did before. When taking into account the type of announcement, Hypothesis 2 is again rejected.

\subsection{Results by industry}

Figure 5 and Table 7 report the results of the abnormal returns analysis for different industries. The plots in Figure 5 show that for Consumer Goods, Consumer Services and Financials, MAD has not changed the stock market behaviour around the publication of an announcement. For Industrials (Panel A) it seems that for bad news announcements, the price reaction prior to an announcement has become larger after the change in market abuse regulation. For Technology (Panel E), the pre-announcement run-up before MAD for bad news announcements is stronger than after MAD.

Looking at the significance of these observations in Table 7, the results for the total sample (Table 4) are only matched by those for the technology industry. For bad news announcements released by firms with the Industrial Classification Benchmark (ICB) classification Technology, the absolute average abnormal returns prior to day zero are significantly larger before MAD than they are in the period after, thus supporting Hypothesis 1. This indicates that for the technology industry, the problem of leakage of information prior to an official press release has significantly decreased since MAD. For the other industries the difference in the 30-day run-up $C A A R$ before and after MAD is not statistically significant.

Looking at the announcement day $A A R \mathrm{~s}$, news announcements do not seem to contain less information after the shift in regulation. All day-zero $A A R$ s are significant and have the expected signs, with the difference between the two regimes being not significantly different from zero. In sum, when the analysis is performed at the industry level, Hypothesis 2 is rejected, while there is strong support in favour of Hypothesis 1.

Looking at the results on the industry level might lead to the conclusion that the change in regulation has had large effects in the technology industry. This is in line with Ahmed and Schneible (2007), who find that small firms and high tech firms drive the effect of US Regulation Fair Disclosure. The numbers presented in Table 8 indicate that the results for Technology are not necessarily driven by a behavioural change within the Technology industry. 

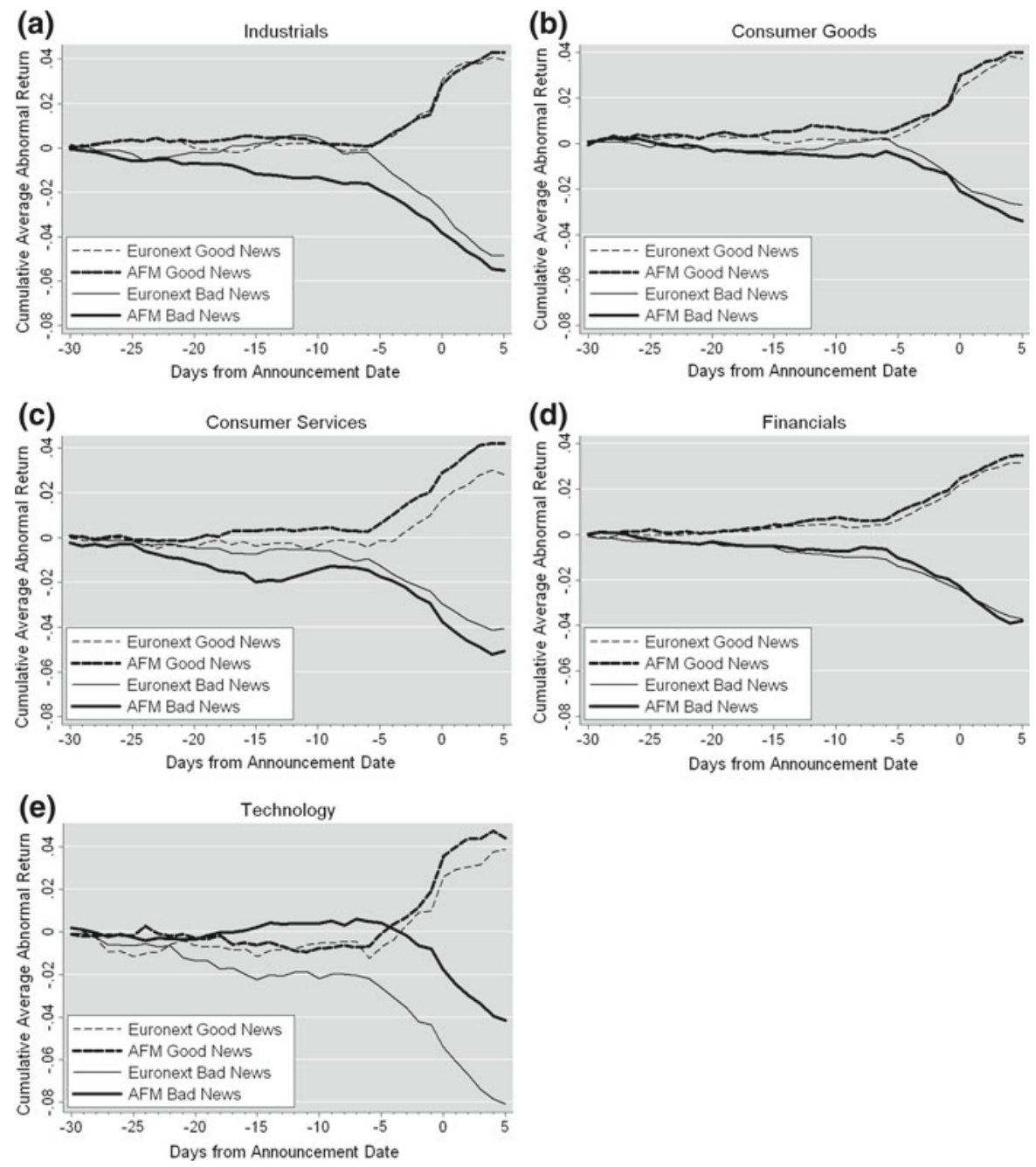

Figure 5 - Plots of cumulative average abnormal returns: by industry

The share of total announcements released by the technology industry that come from small capitalization firms is $44.5 \%$.

Looking at the results from the analysis for small cap firms (e.g., Table 4), the results for Technology can be said to be strongly affected by the underlying behavioural change observed for small capitalization firms. Table 8 then also gives and indication to why no effects are found for the other industries. The shares of announcements made by small capitalization firms within the other industries are very small, ranging from $2.8 \%$ for Consumer Services to $11.5 \%$ for Financials. 


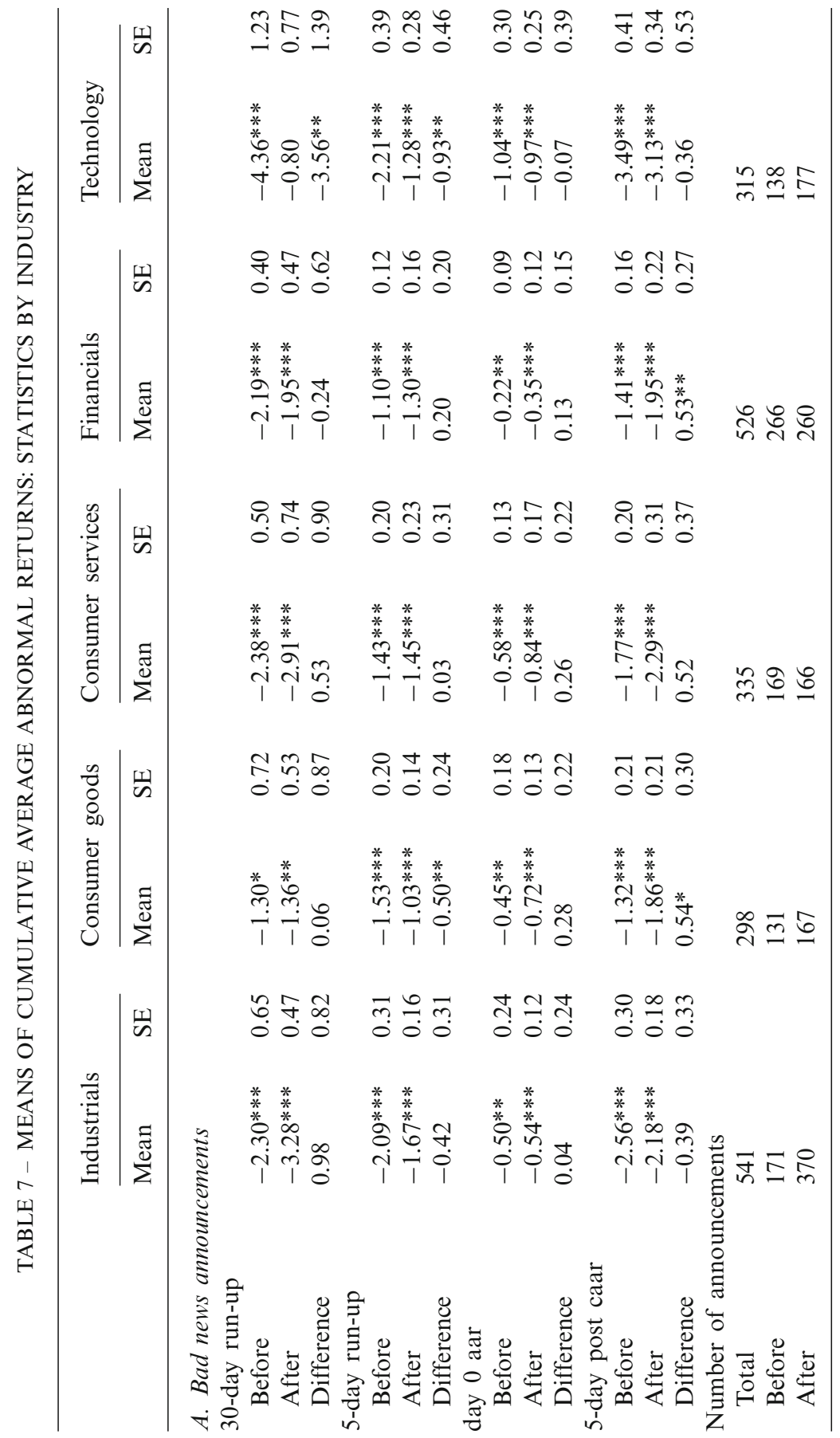


TYAS PREVOO AND BAS TER WEEL

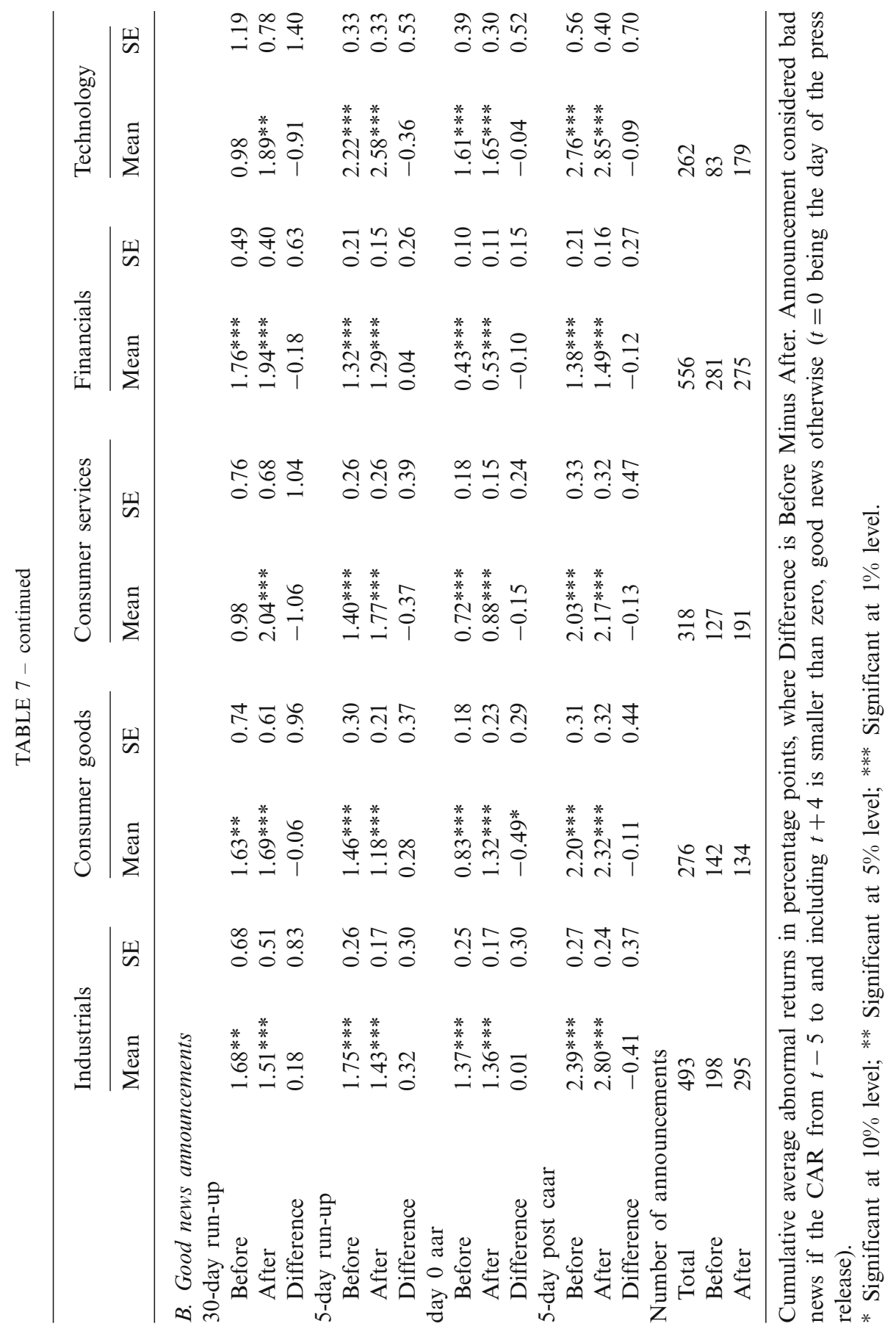


TABLE 8 - NUMBER OF ANNOUNCEMENTS BY INDUSTRY AND CAPITALIZATION

\begin{tabular}{lcrrr}
\hline Industry & \multicolumn{2}{l}{ Capitalization } & & Total \\
\cline { 2 - 4 } & Large & Mid & Small & \\
\hline Industrials & 393 & 568 & 73 & 1,034 \\
Consumer goods & 423 & 95 & 56 & 574 \\
Consumer services & 395 & 240 & 18 & 653 \\
Financials & 635 & 323 & 124 & 1,082 \\
Technology & 145 & 175 & 257 & 577 \\
Total & 2,711 & 1,650 & 618 & 4,979 \\
\hline
\end{tabular}

\section{ROBUSTNESS}

The results presented in the previous section might be sensitive to changes in the sample to which the analysis is applied, and may also be different when changes are made in the analysis itself. To investigate the robustness of the reported results, this section provides a number of checks by applying the analysis to various subsamples and by applying some changes to the approach itself. Only the abnormal returns analysis is repeated here, since the results for the volumes analysis are less reliable when smaller samples are selected.

\subsection{Distinguishing good and bad news}

The method of determining whether an announcement contains good or bad news is subject to a number of assumptions. Wong (2002) makes a distinction between bad and good news announcements based on the sign of the abnormal return on the announcement day. As noted previously, this may be wrong and therefore the distinction in the analyses of this paper has been based on the CAR of the period $t=-5$ to $t=4$. To compare the previously reported results to Wong's (2002) approach, the results of the analysis using the sign of the day zero abnormal return to define bad vs. good news are reported in Figure 6 and Table 9.

Looking at the plots in Figure 6, the conclusions for the total sample concerning a cleaner market do not seem to be affected by the way bad news is distinguished from good news: there are no apparent differences between the two regimes. This is confirmed when looking at Table 9. The 30-day run-up for the total sample is insignificant, both for bad news announcements and good news announcements. The differences are also insignificant. The absolute day zero $A A R$ s are positive and highly significant, with no differences 
(a)

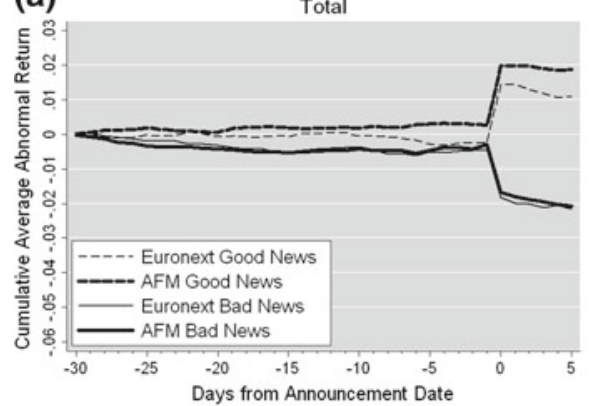

(c)

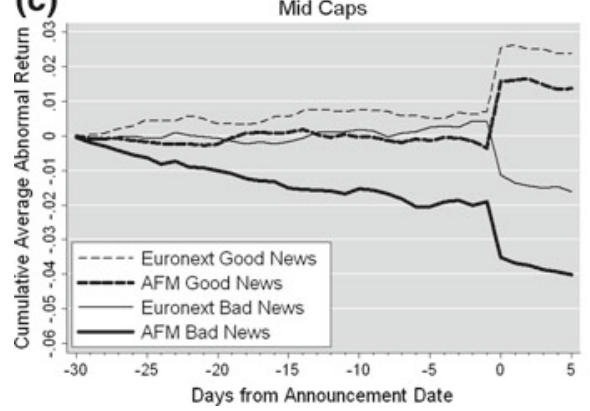

(b)

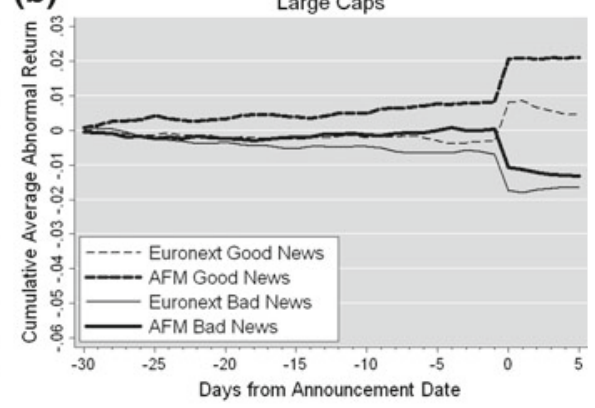

(d)

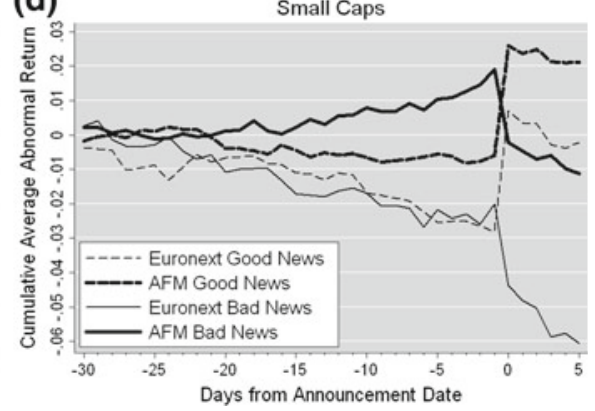

Figure 6 - Plots of cumulative average abnormal returns: bad/good news distinction by sign of announcement day abnormal return

before and after MAD. This would indicate that the Amsterdam stock market is clean, with no suspicion of information leakage or illegal insider trading.

This conclusion changes when the data is separately analysed for the different capitalization sizes. The results for large caps are in line with those obtained from the original analysis, leading to inconclusive results for large caps. For mid caps the results suggest that the absolute 30-day pre-announcement $C A A R$ for bad news announcements are larger after MAD. The mid caps analysis with the initial approach provides slight support in favour of a cleaner market. The results for small caps seem to be in line with those from Table 1, where the difference in the 30-day run-up for bad news announcements was also significant. However, the significant difference results here from a puzzling positive run-up after MAD.

A positive run-up for a bad news announcement is possible if the market anticipation of the content of the announcement is not in line with the actual information in the announcement. For instance, if the market anticipates a positive earnings announcement, whereas it actually turns out that earnings have been lower than expected, the run-up can be positive, with a negative day zero abnormal return. This may be the case on the level of an individual announcement, but due to averaging out this observation will not 
THE EFFECTS OF A CHANGE IN MARKET ABUSE REGULATION

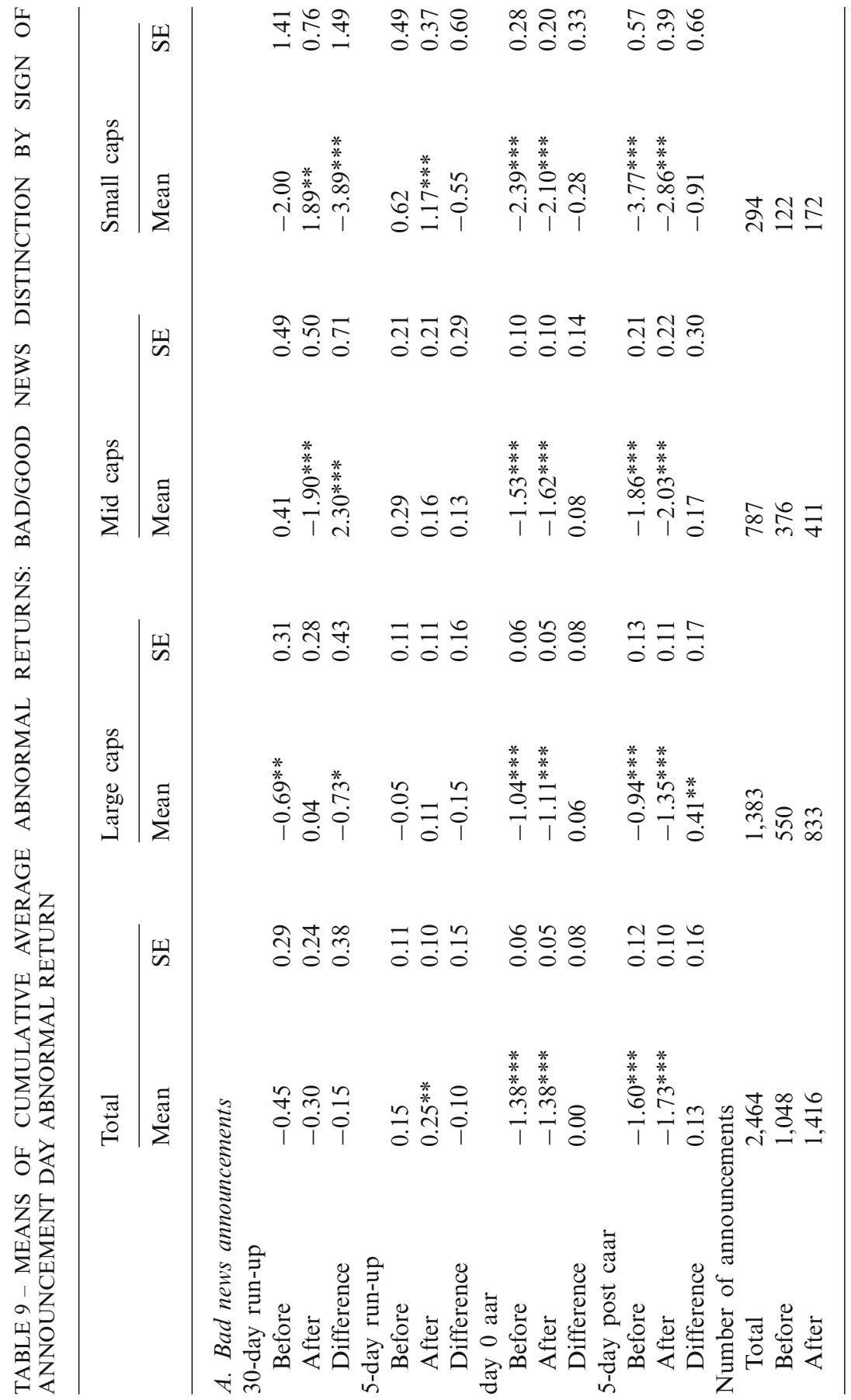


TYAS PREVOO AND BAS TER WEEL

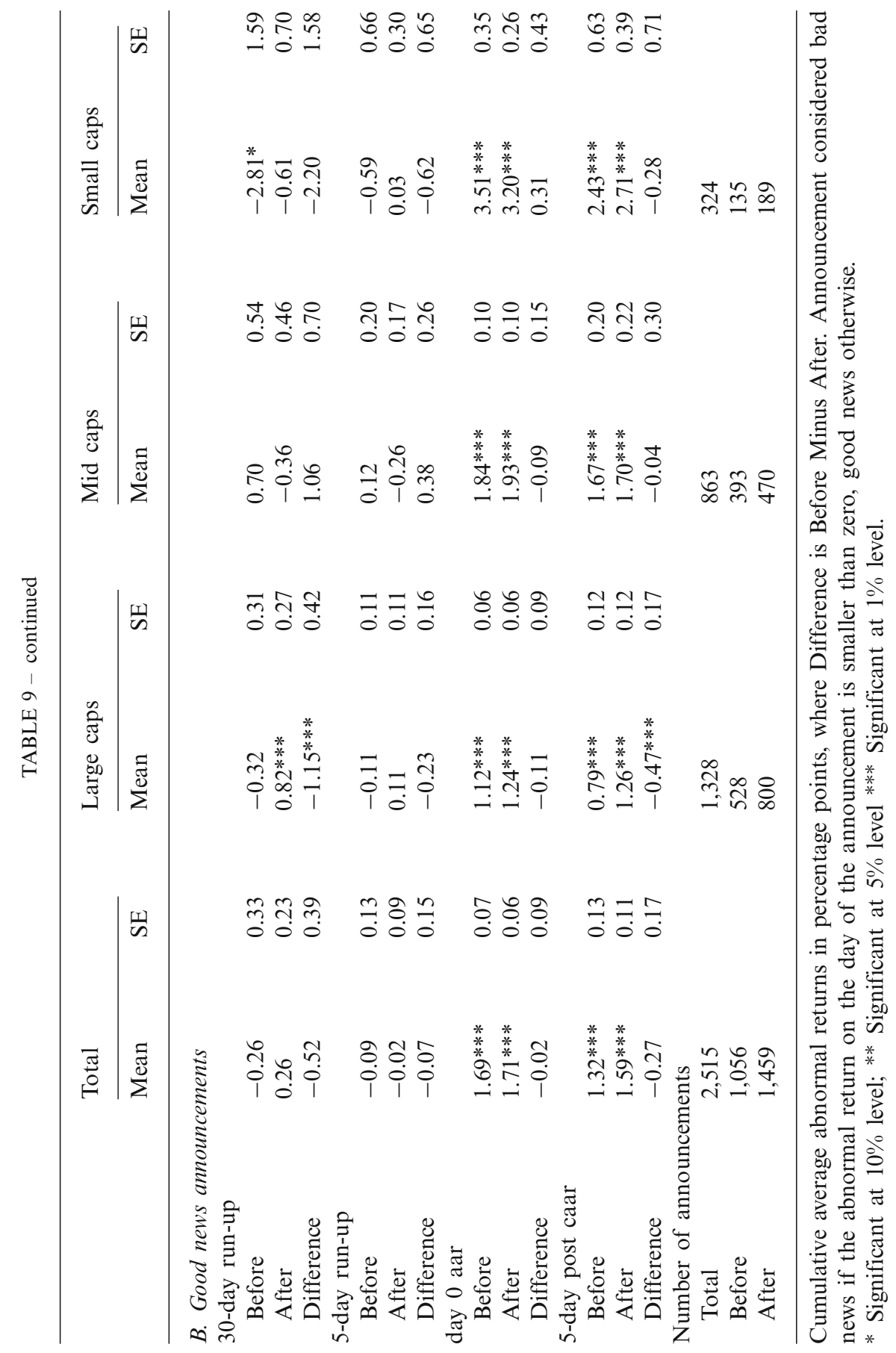


occur after all announcements have been aggregated. There are two possible explanations for this result to remain visible at the aggregate level. The first is that the market's anticipation of results is repeatedly incorrect. However, this explanation assumes that investors do not alter their expectations. If the market as a whole is constantly surprised by the contents of an announcement, it will alter the ways in which expectations are formed.

The second explanation for why this observation may occur at the aggregate level is that information leakage and illegal insider trading trouble the market. If an announcement contains good news, but insiders have traded on that information prior to its official release - thus leading to a positive and significant pre-announcement run-up - a negative announcement date abnormal return may appear if these insiders (and other investors mimicking their trades) sell their stocks to cash in the profits obtained. In this case, good news will be classified as bad news when using the day zero abnormal return to make the distinction.

By basing the distinction between bad and good news on the sign of the $C A R$ of the 10-day period from $t=-5$ to $t=4$ (with the announcement day being $t=0$ ) this problem of miss-specifying good news as bad news is diminished, although it still remains if the information in the announcement is fully reflected in the stock prices as early as six days prior to the official announcement. A second issue is the possibility that the press release obtained from the database is not the first announcement containing the information. It could be that the announcement was published sooner in other media. But again, by using the 10-day period to make the bad/good news distinction, the problems this issue may cause are diminished. Furthermore, these two problems can lead to reversed results on the announcement level, yet since the analyses in this paper involve averages over large numbers of announcements, the results are not likely to be strongly affected.

\subsection{Clustering}

In the case an announcement is preceded by a prior announcement by the same firm within the run-up period, the price reaction of this prior announcement will show up in the $C A R$ of the later announcement. This gives rise to an unjustified suspicion of information leakage and illegal insider trading prior to the official release of the announcement. To look into this issue the announcements that are accompanied by another announcement by the same firm in the period from $t=-5$ up to and including $t=4$ are excluded from the analysis.

Since this reduced sample still includes announcements that are preceded by announcements prior to 5 days before its announcement, only the 5-day run-up is considered. Considering only announcements containing no other 
announcements in the complete period from $t=-30$ to $t=4$ will leave too small a sample to be able to draw reliable conclusions from the results.

Table 10 shows the results for the reduced sample of unclustered announcements. The results for bad news announcements are in line with those obtained from the total sample, including the clustered announcements. The results for good news announcements show that the market is cleaner after MAD, whereas this was rejected when applying the analysis to the samples including the clustered announcements. Furthermore, there is also support for the idea that news announcements have become more newsworthy after the shift in supervision on 1 October 2005, thus rejecting Hypothesis 2.

\subsection{Two-factor market model}

The approach used in the previous section regresses the returns of the individual security on the returns of the relevant capitalization index. So for an announcement by a small cap firm the returns of the firm are regressed on the returns of the AScX. To increase the explanatory power, it may be useful to add additional explanatory variables. This section discusses changes in the results when adding the returns of the relevant industry as an explanatory variable to the market model. The return for any security $i$ at time $t$ is now given by

$$
R_{i, t}=\alpha_{i}+\beta_{i} R_{C, t}+\gamma_{i} R_{I, t}+\varepsilon_{i, t},
$$

where $R_{i, t}$ is the return on security $i$ at time $t, R_{C, t}$ is the return on the relevant capitalization index $C$ at time $t$, and $R_{I, t}$ is the return on the relevant industry index $I$ at time $t$. For each announcement this equation is then estimated with an estimation window of 120 days and the abnormal returns are defined as

$$
A R_{j, t}=R_{j, t}-\left(\hat{\alpha}_{j}+\hat{\beta}_{j} R_{C, t}+\hat{\gamma}_{j} R_{I, t}\right),
$$

where $A R_{j, t}$ is the abnormal return on announcement $j$ at time $t$, where the returns are those of the security releasing announcement $j$. Thus, $\hat{\alpha}_{j}, \hat{\beta}_{j}$ and $\hat{\gamma}_{j}$ are the estimates of the market model parameters for announcement $j$. Time $t$ is here relative to the date of the news announcement, with $t=0$ being the announcement day.

An estimation of the model in Eq. (14) will suffer from multicollinearity, since the return of a security is regressed both on the return of the cap index and the return of the industry index. These two indices are obviously not unrelated. The industry indices are obtained from NYSE Euronext and are based on the ICB classification. They are subsamples of the Amsterdam AllShares Index (AAX), as are the cap indices. The correlation between the cap and industry indices affects the interpretation of the coefficients of the 


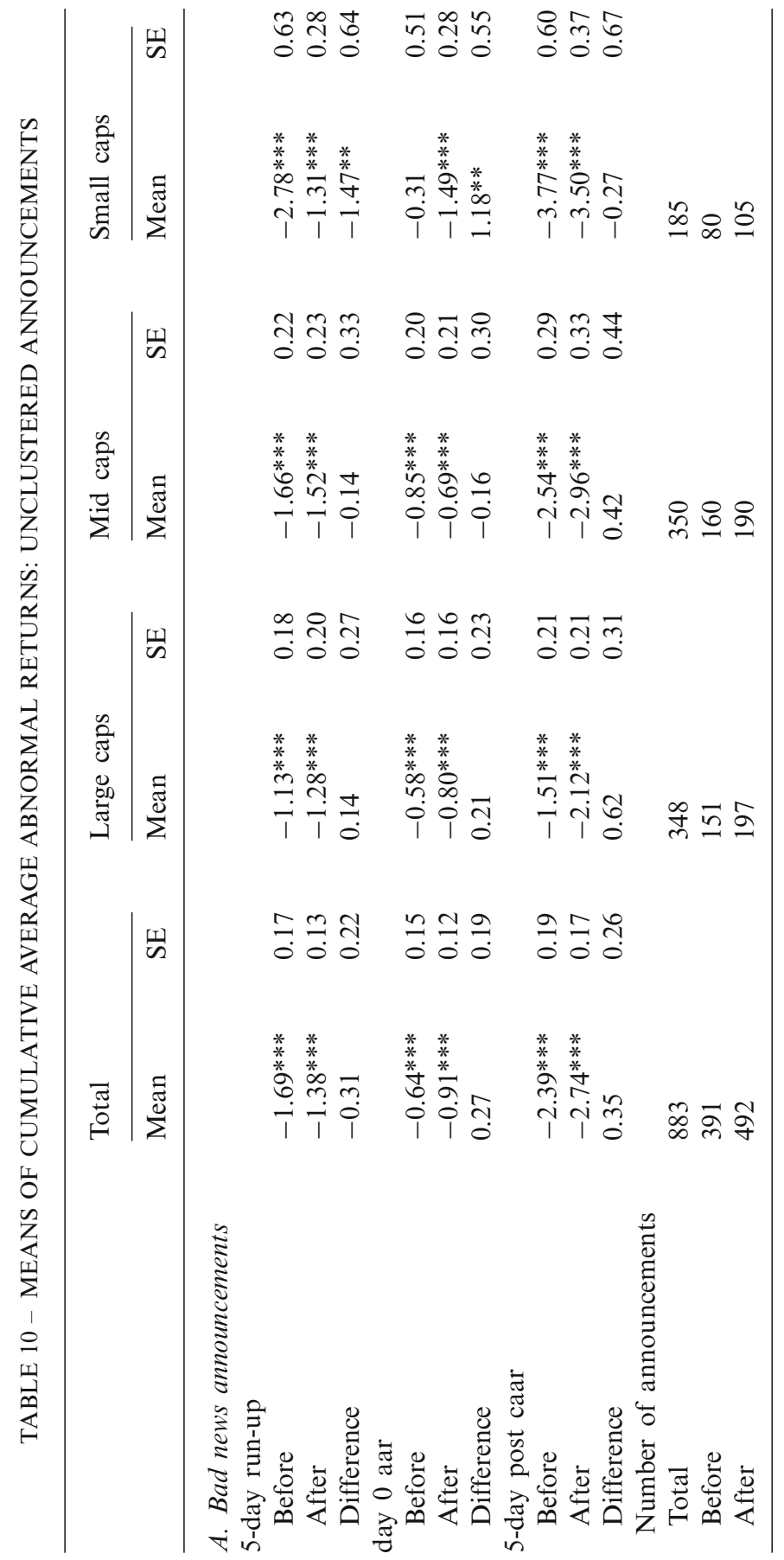


explanatory variables, but as long as the relationship between the indices is stable over time, the forecast is still reliable.

The change in the results will be most pronounced for the results of the analysis by industry (Table 7), so Table 11 reports the results of the analysis using the two-factor market model by industry. The conclusions from the results for Industrials, Consumer Goods, Consumer Services and Financials are the same as those from the one factor market model used in Section 5. The results for the Technology industry provide more support for the suspicions formulated earlier. Using the original one factor market model the results for Technology are consistent with a cleaner market, whereas it is suspected that the significant difference is caused by the fact that a large portion of the announcements within the technology sample are issued by small capitalization firms. Adding the industry index return to the market model improves the fit of the model.

To conclude this section, the results hold up to the robustness checks. First, basing the distinction on the abnormal return of the announcement day does not change the conclusions about the changes due to the shift in supervision. However, using the day zero $A R$ instead of the $C A R$ of a period surrounding the announcement, good news announcements may be wrongly classified as bad news announcements.

Second, adjusting for the issue of clustering also influences the results, in the sense that the market is cleaner and press releases contain the same information before and after MAD.

Finally, adding the industry index return to the market model as an extra explanatory variable improves the fit of the model, yet the problem with adding the industry index return to the model is that if a certain industry index is heavily influenced by a small number of firms, price reactions surrounding announcements by these firms will turn up in the industry index, which will cause these announcements not to be associated with high abnormal returns, although the price reactions are caused by them.

\section{DISCUSSION AND CONCLUDING REMARKS}

This paper has evaluated the effects of the transfer of supervision of the publication of price-sensitive information by companies listed on the Amsterdam Stock Exchange. The first hypothesis is that MAD has decreased the cumulative average abnormal return and cumulative average abnormal volume prior to the public release of news announcements. The results are inconclusive for large and medium sized firms, whereas the hypothesis cannot be rejected for small firms. This is in line with what is found for the effects of the US Regulation Fair Disclosure, where the effects are most pronounced for small firms (see Collver (2007), for a discussion). Presenting the results for different types of corporate news announcements, the results show that the market is cleaner 
TYAS PREVOO AND BAS TER WEEL

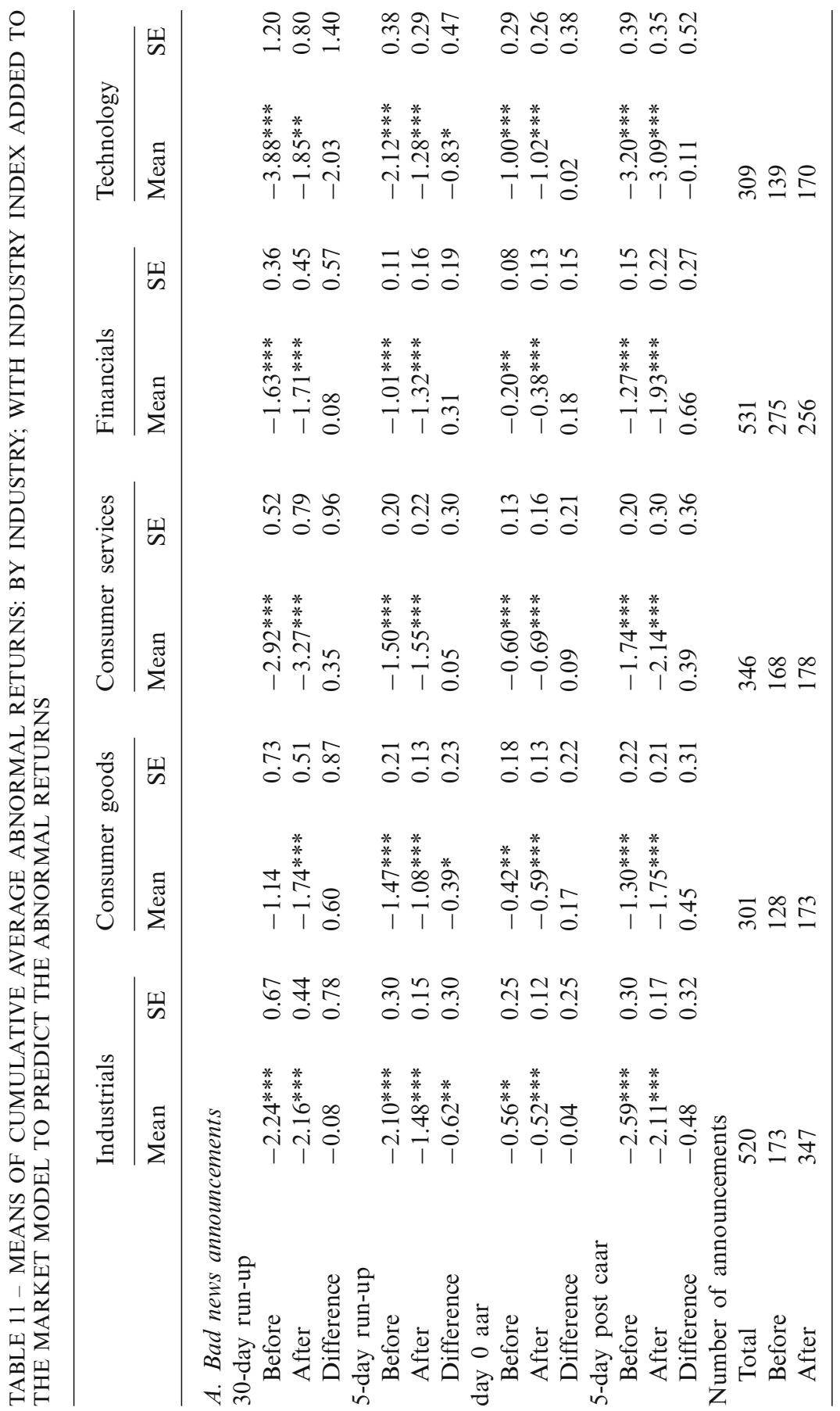


THE EFFECTS OF A CHANGE IN MARKET ABUSE REGULATION

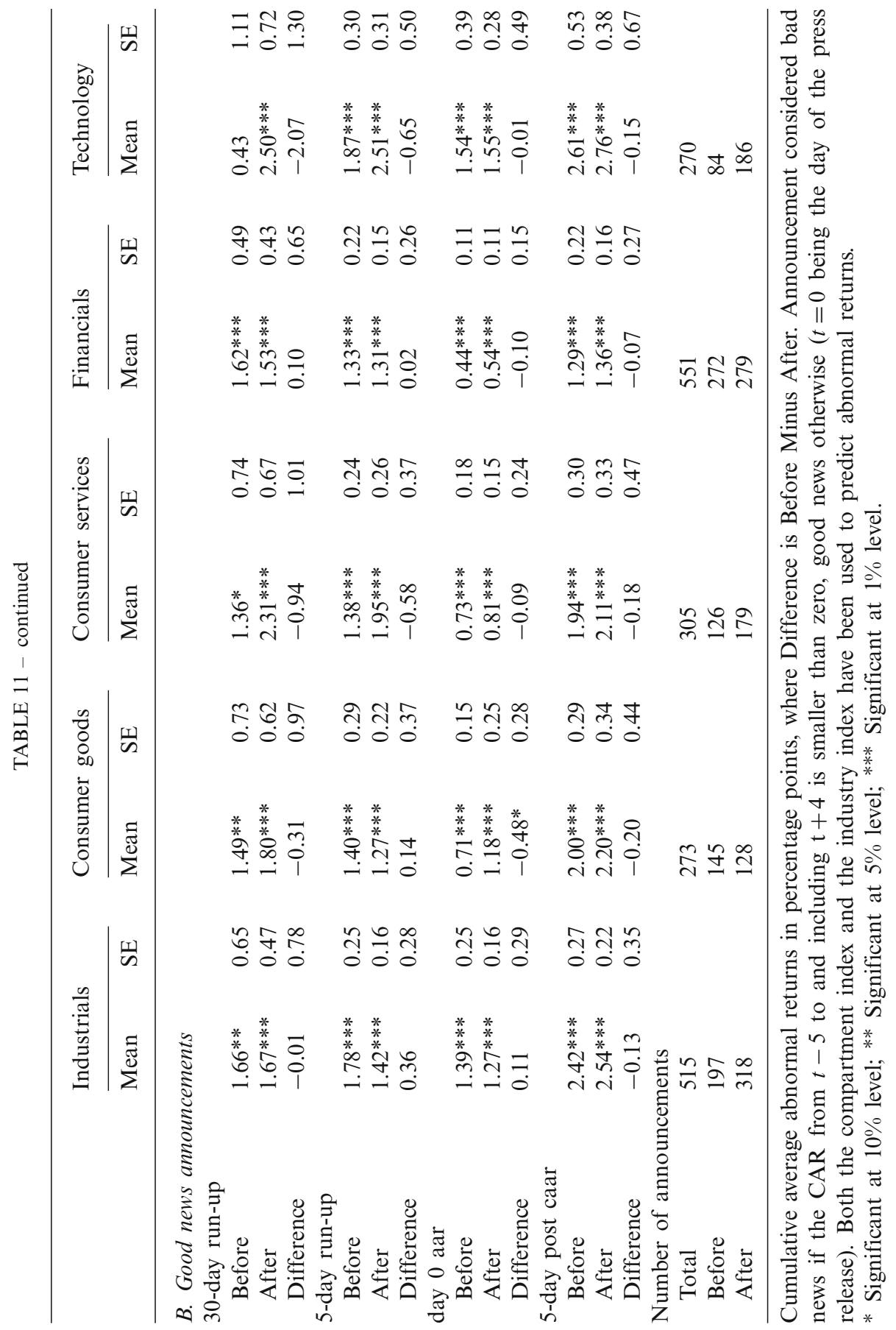


for Alliances/M\&A announcements. For announcements of this type, containing good news, the suspicious pre-announcement run-up observed before 1 October 2005 is not longer present afterwards.

An important note to these results presented is the dependence of certain characteristics of the corporate news announcements to the supervisor. The type of announcement is not independent of the supervisor, nor is the cap size of the firm publishing the announcement. Therefore the analysis is applied to cap sizes separately and to announcement types separately. The results are only significant for small cap firms and for announcements of the type Alliances/M\&A, indicating that the new regulation improves the cleanliness of the market for these samples. However, an untabulated test of independence between these two characteristics shows that the null hypothesis of independence is rejected after MAD at the 1\% level, and before MAD at the $10 \%$ level. Looking at numbers of announcements, $21 \%$ of small cap announcements (76 out of 361) in the period after MAD are of the type Alliances/M\&A, whereas this share is only $10 \%(25 / 257)$ prior to the new regulation. Further research has to determine whether the results depend on cap size or on announcement type, with the results here being a strong first-stage signal.

With the observation that the number of announcements increased after 1 October 2005 the question arose if the information content of these announcements was still as high as before. The results from the analyses presented in this paper lead to the rejection of Hypothesis 2, that there is less information per press announcement, meaning that the information level of announcements after MAD has not decreased. Although the difference in the absolute $A A R$ s before and after MAD is found not to be significant, in most cases the absolute $A A R$ s are actually larger afterwards, indicating that announcements are more informative since MAD.

Hallock and Mashayekhi (2003) investigate whether news announcements have become less newsworthy over the period 1970-2000. He actually finds that for earnings announcements the share price reaction around the announcement date has increased over the years. If this trend also applies to the Amsterdam Stock Exchange, it becomes less straightforward to interpret the results in this paper. The increase observed in the announcement day absolute abnormal return after the shift in supervision might then not be a result of the change in regime, but rather the result of a positive time-trend in the share price reaction to news announcements. Further research has to determine whether or not this upward trend is large enough to nullify or even reverse the results obtained in this paper. The returns then have to be corrected for this upward trend and the information content of releases needs to be re-evaluated. 
The conclusions regarding the information content of releases might be biased for another reason. If the increase in the number of announcements after the implementation of MAD really is only temporary, the period over which to apply the analysis should not include this period of adaptation to the new regulation. Given that news announcements do not contain less information using the period analysed in this paper, removing the adaptation period, which is associated with more and possibly less informative announcements, will only strengthen the confidence with which the hypothesis is rejected. The results using a post-adaptation period are even likely to be consistent with a hypothesis that news announcements are more informative after MAD.

Even though the amount of suspicious trading is lower after MAD, the 30-day run-up $C A A R$ s are significant in most cases, even after the change in regulation. This significant run-up is an indicator for the presence of information leakage and illegal insider trading, but it does not allow for a strong conclusion regarding the extent of the problem. Elliott et al. (1984) investigate the issue of insider trading from a different perspective. With trading behaviour by corporate insiders being found to be profitable, they test whether this profitable trading by insiders in general is related to the public release of information. They show that most insider trading does not seem related to news announcements. Meulbroek (1992) shows that less than half of the pre-announcement stock price run-up observed before takeovers occurs on insider trading days. This means that although half of the run-up seems to be caused by corporate insiders, investors who are not obliged to register their trades cause the other half. Sanders and Zdanowicz (1992) find that the target firm stock price run-up found by other researchers begins prior to the public news announcement, which gives rise to the suspicion of use of nonpublic information and hence of illegal insider trading. However, they also find that this run-up only starts after an unpublicised initiation of the transaction.

A final issue worth noting and worth further investigation is that of clustering, which was briefly discussed in Section 6. If an announcement is preceded by another announcement, the price reaction to this first announcement will show up in the pre-announcement run-up periods for the firm at hand. This problem probably extends beyond the firm level. A firm's stock price can also be influenced by announcements made by other firms. Within the financial industry, for example, an announcement by Bank1 might have an effect on the stock price of Bank2. If this announcement is followed by an announcement by Bank2, Bank2 will show significant pre-announcement abnormal returns. In terms of the analysis applied here, this would lead to a suspicion of illegal insider trading, whereas the run-up was actually caused by the announcement by Bank1. This problem has partially been taken care of by adding the industry index as a factor in the market model (Section 6.3). 
Further research is necessary to investigate the extent to which this affects the results from this analysis.

Also, clustering of announcements could lead to an under- or overestimation of the pre-announcement run-up and thus influence the conclusions regarding the prevalence of illegal insider trading on the Amsterdam stock market. If insiders trade on information to be released in future news announcements, the detection of this illegal insider trading will depend on other announcements by the same firm within the 30-day pre-announcement period. If it concerns a good news announcement, run-up $C A R$ will be positive in the case of illegal insider trading, and if in the run-up period another good news announcement occurs, the run-up $C A R$ will be even larger, increasing the significance of the run-up. However, if a bad news announcement occurs in that same run-up period, the positive run-up caused by the illegal insider trading will be diminished by the market reaction to the bad news announcement, thereby decreasing the detection of illegal insider trading. If the shares of good news and bad news announcements present in the 30-day run-up period are equal and if the issue of clustering is comparable in both periods, the effect of increased and decreased probability of detection will average out when taking the average $C A R$ s over the total samples. However, if these conditions do not hold, the results presented here are biased due to the bias present in the clustering of announcements.

\section{APPENDIX I}

Table 12 gives the number of announcements that have been released by an individual security within different capitalization sizes and within different time periods. For example, the first security in the list (Aalberts) published 11 announcements in the 15 months prior to MAD coming into effect. At the time of publication of these 11 announcements, Aalberts was classified as a mid cap. It also released 11 announcements in the 15 months following 1 October 2005. At the time of their release, for 2 of these 11 Aalberts was classified as a mid cap, whereas for the other 9, it was classified as a large cap.

Depending on the composition of the total number of announcements released by a single security, its daily volume is included in either one of the three market volume indices or in none at all. If the share of its total announcements published within a single cap size group is larger than $95 \%$, the daily volume of that listing is used in the construction of the market volume index for that cap size. Table 13 tabulates which industries are used in the construction of the three market volume indices. 
THE EFFECTS OF A CHANGE IN MARKET ABUSE REGULATION

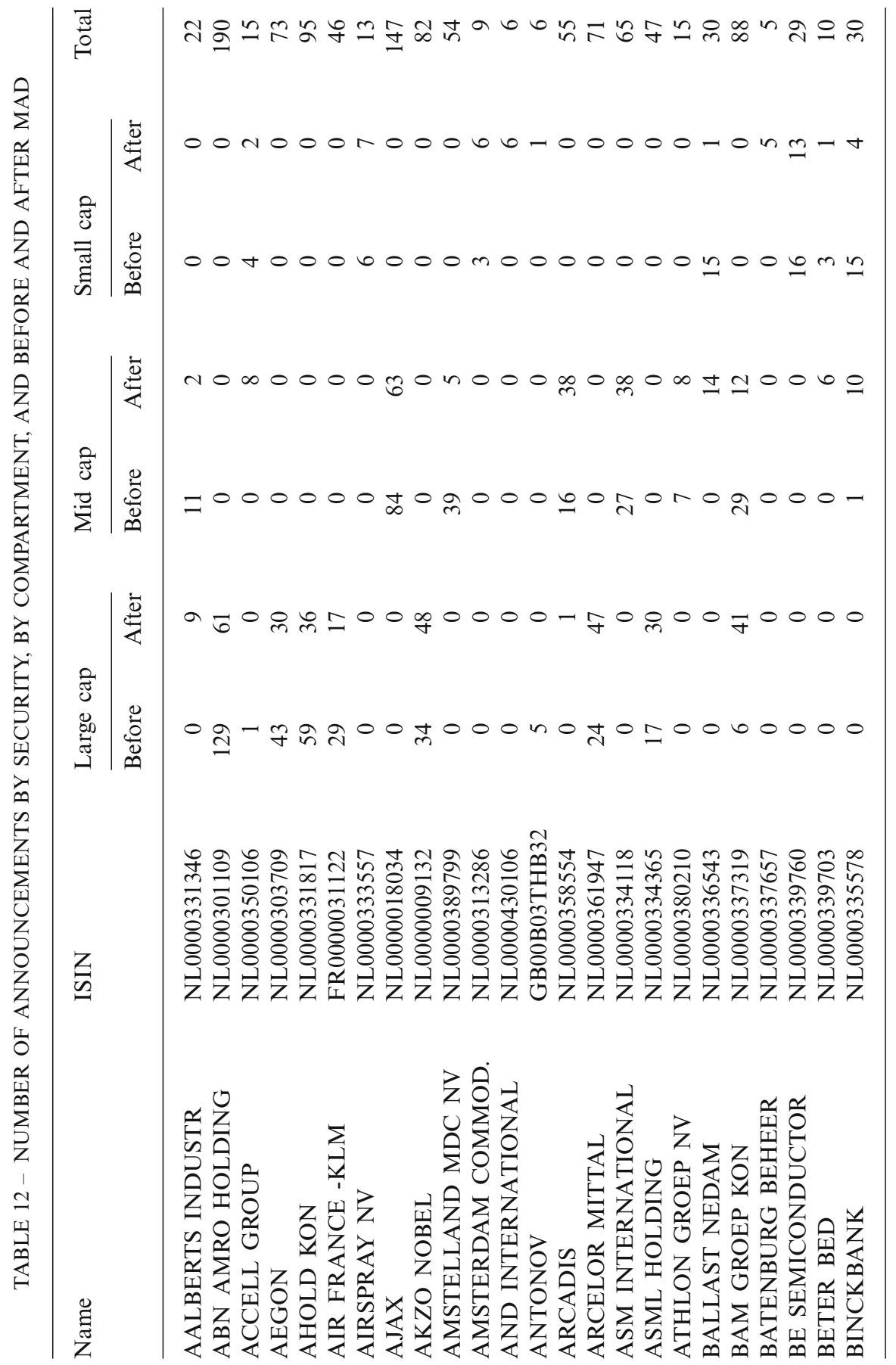




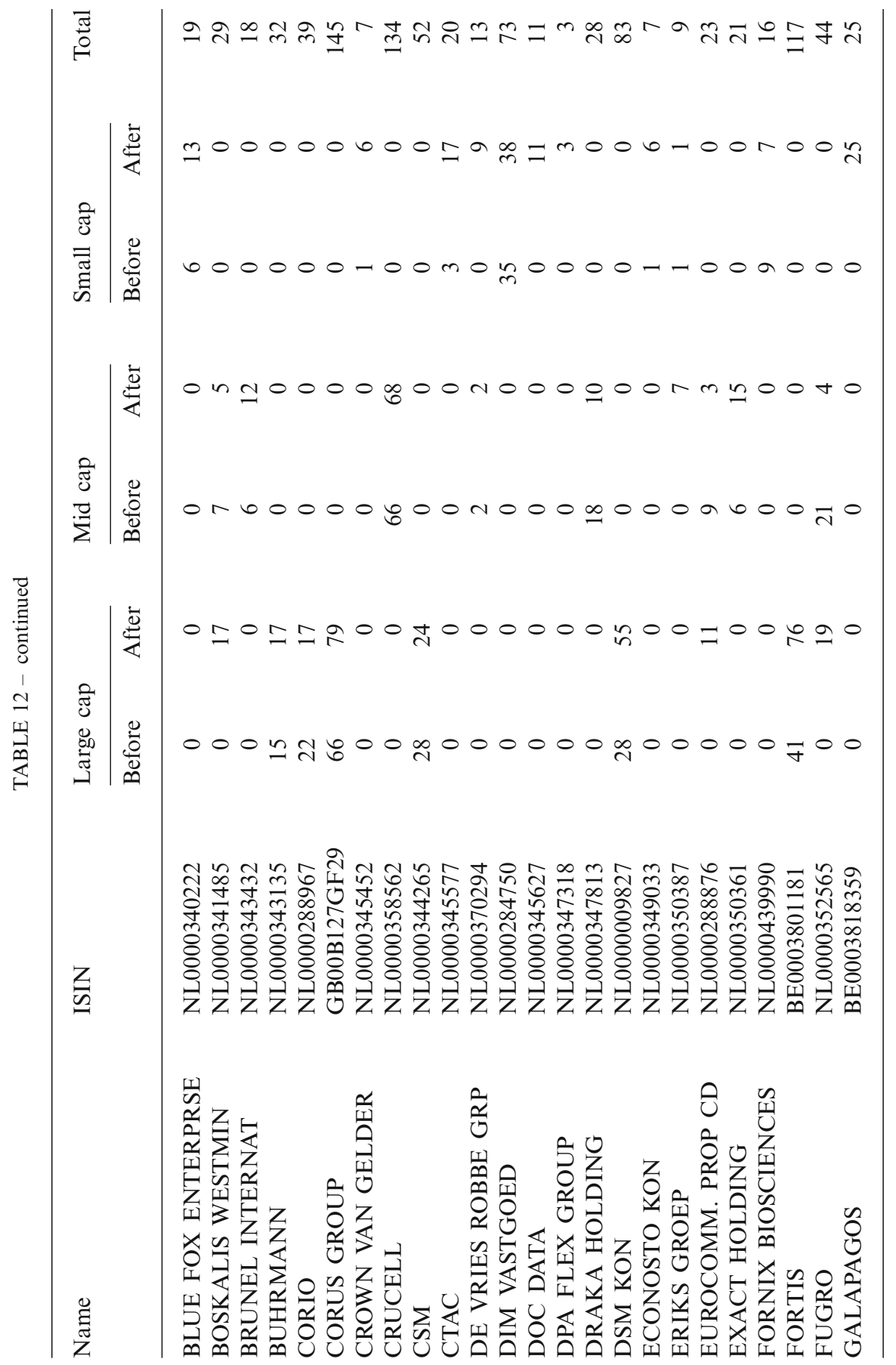


THE EFFECTS OF A CHANGE IN MARKET ABUSE REGULATION

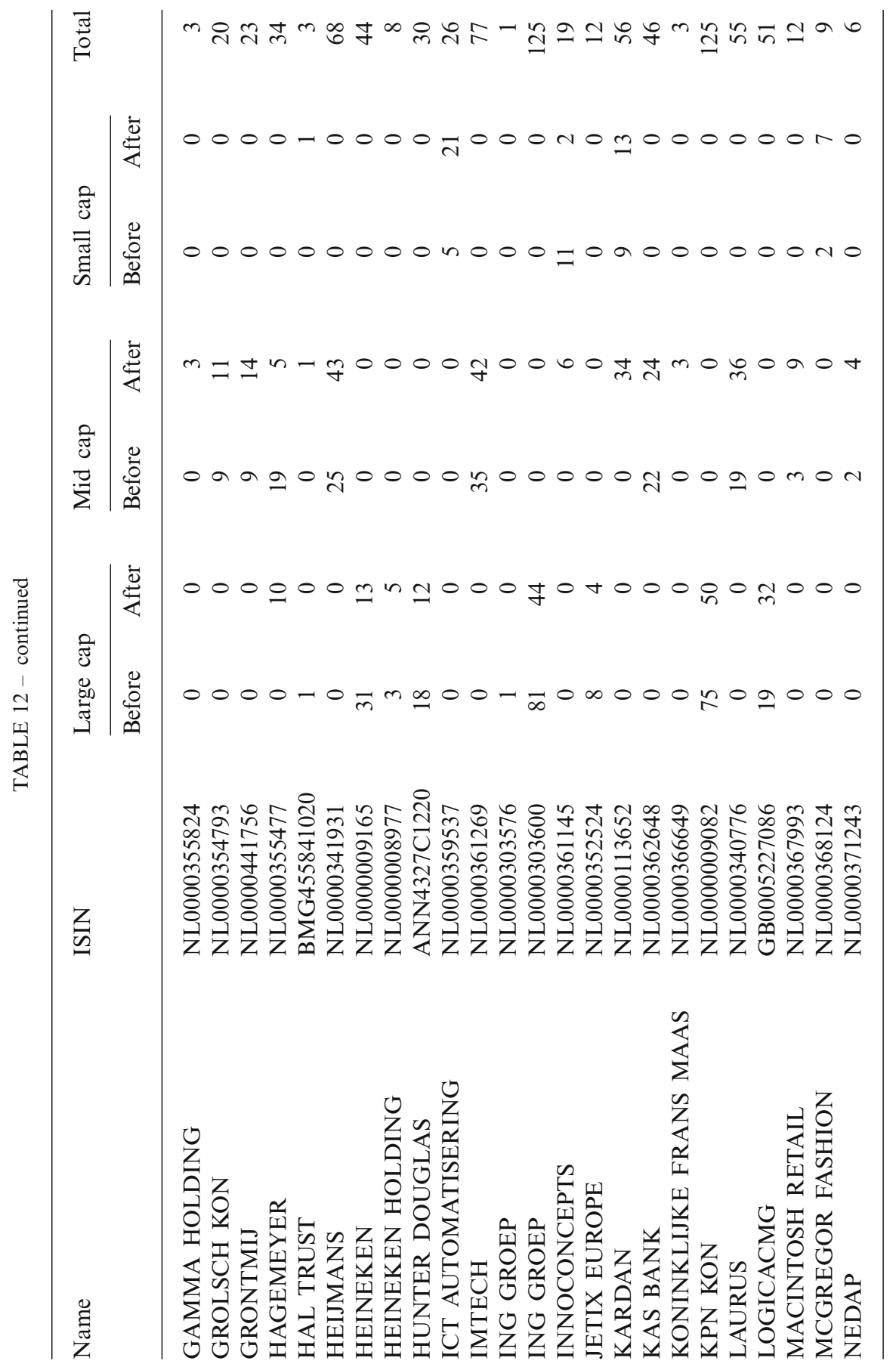


THE EFFECTS OF A CHANGE IN MARKET ABUSE REGULATION

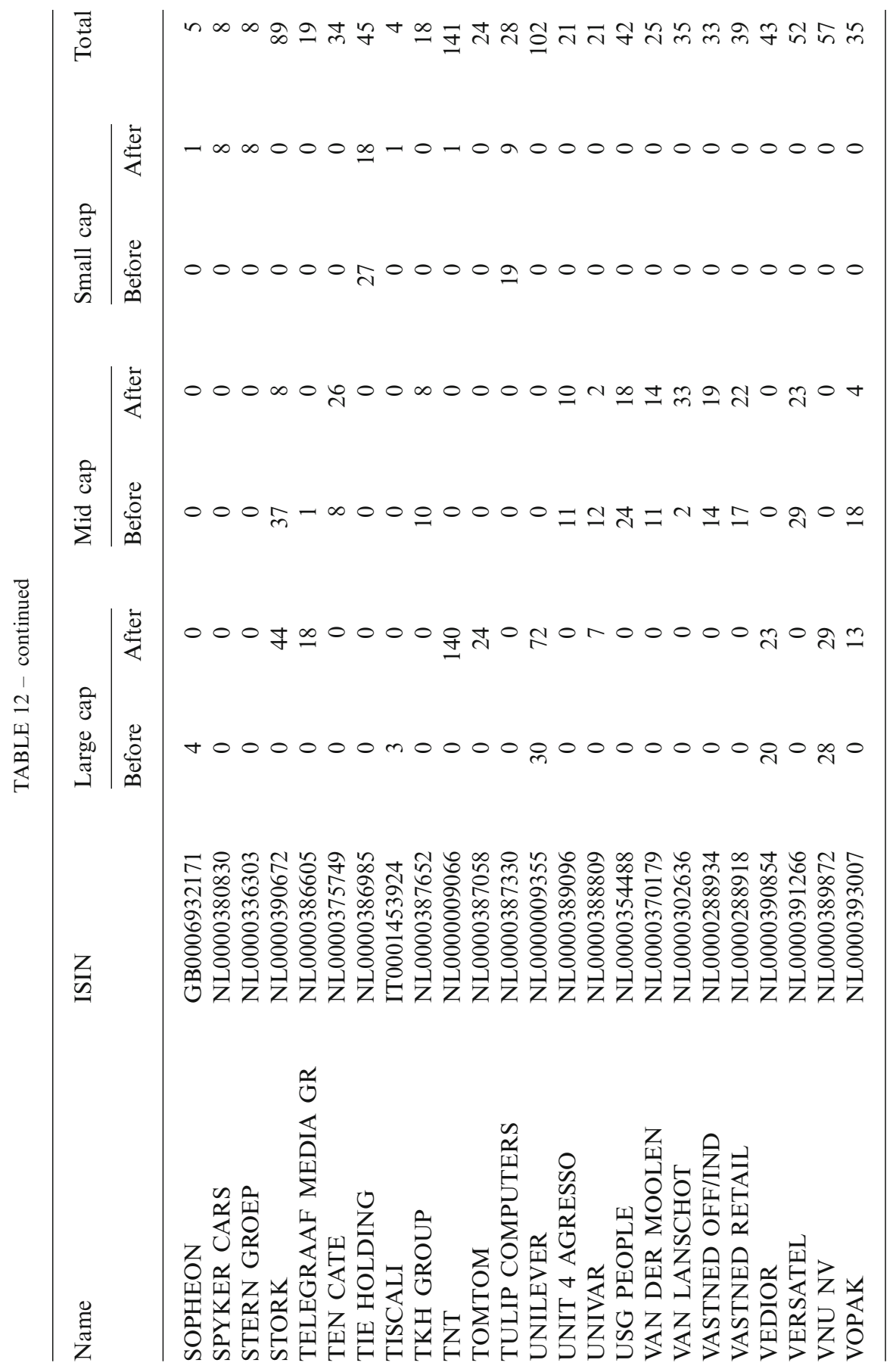




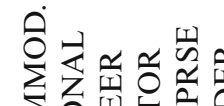

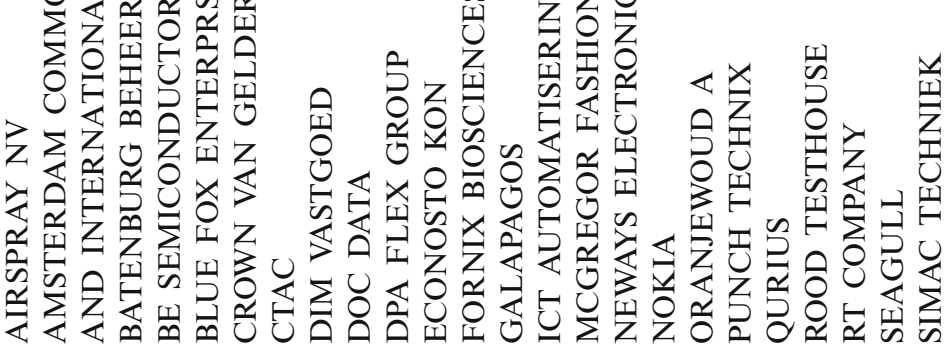

之े

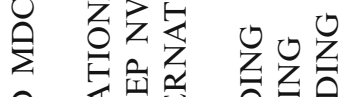

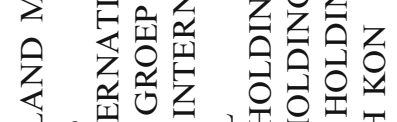

$\sum_{\sum}^{\infty}$

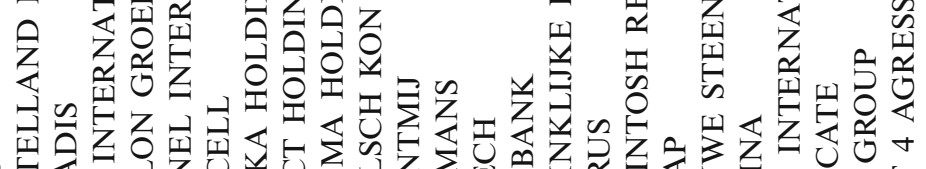

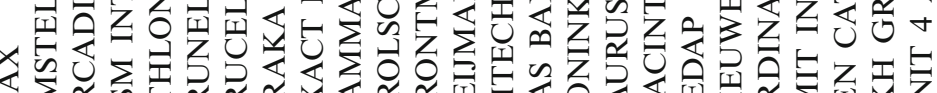

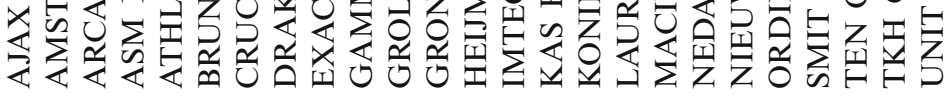




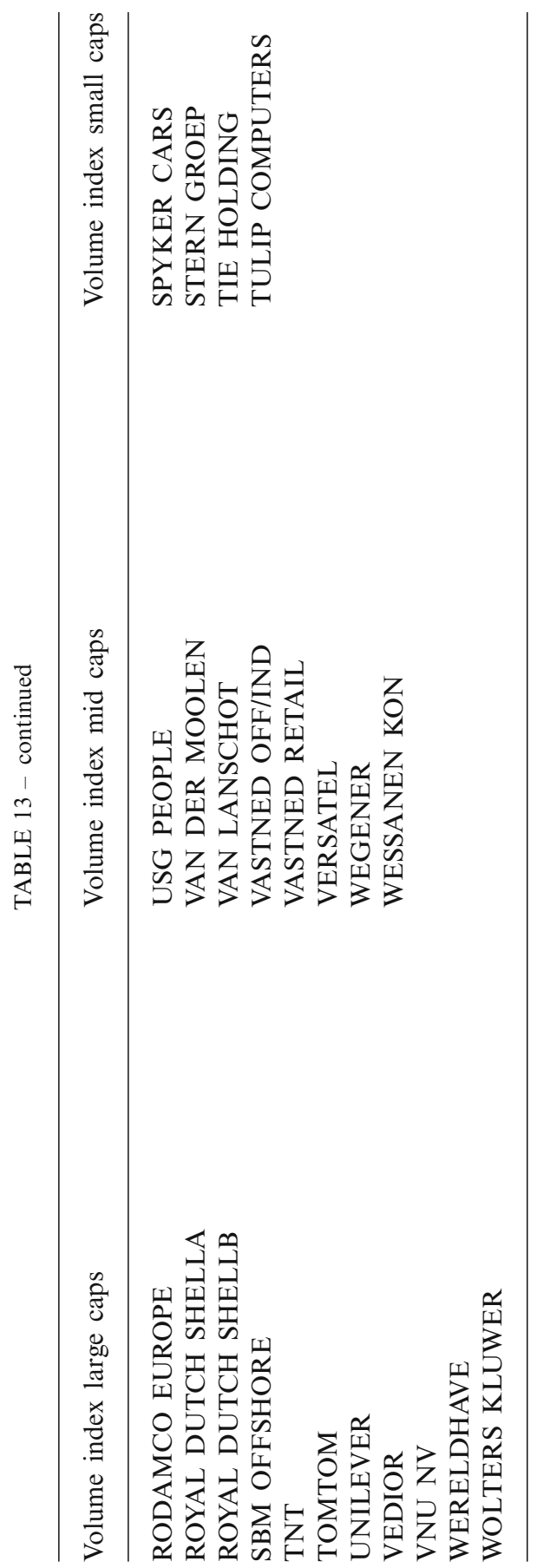




\section{APPENDIX II}

Table 14 provides an overview of the different types of announcements and their appearance before and after the introduction of MAD.

TABLE 14 - DIVISION OF ANNOUNCEMENTS IN EURONEXT CORPORATE NEWS DATABASE IN 9 ANNOUNCEMENT TYPES

\begin{tabular}{|c|c|c|c|c|}
\hline Announcement type & Topics & Before & After & Total \\
\hline \multirow[t]{7}{*}{ Alliances/M\&A } & $\begin{array}{l}\text { Alliances and } \\
\text { agreements }\end{array}$ & 0 & 7 & 7 \\
\hline & $\begin{array}{l}\text { Alliances and } \\
\text { agreements other } \\
\text { subject takeover bids } \\
\text { joint venture mergers, } \\
\text { acquisitions, transfers }\end{array}$ & 40 & 3 & 43 \\
\hline & $\begin{array}{l}\text { Alliances and } \\
\text { agreements takeover } \\
\text { bids joint venture } \\
\text { mergers, acquisitions, } \\
\text { transfers }\end{array}$ & 187 & 524 & 711 \\
\hline & Joint venture & 0 & 22 & 22 \\
\hline & $\begin{array}{l}\text { Joint venture mergers, } \\
\text { acquisitions, transfers }\end{array}$ & 0 & 1 & 1 \\
\hline & $\begin{array}{l}\text { Mergers, acquisitions, } \\
\text { transfers }\end{array}$ & 0 & 13 & 13 \\
\hline & Takeover bids & 0 & 4 & 4 \\
\hline Alliances/M\&A total & & 227 & 574 & 801 \\
\hline \multirow[t]{2}{*}{ Sales } & Sales & 68 & 99 & 167 \\
\hline & Sales other subject & 29 & 0 & 29 \\
\hline Sales total & & 97 & 99 & 196 \\
\hline \multirow[t]{2}{*}{$\begin{array}{l}\text { Share introductions and } \\
\text { issues }\end{array}$} & $\begin{array}{l}\text { Other subject share } \\
\text { introductions and } \\
\text { issues }\end{array}$ & 0 & 2 & 2 \\
\hline & $\begin{array}{l}\text { Share introductions and } \\
\text { issues }\end{array}$ & 17 & 481 & 498 \\
\hline $\begin{array}{l}\text { Share introductions and } \\
\text { issues total }\end{array}$ & & 17 & 483 & 500 \\
\hline \multirow[t]{3}{*}{ Commercial operation } & Commercial operation & 0 & 8 & 8 \\
\hline & $\begin{array}{l}\text { Commercial operation } \\
\text { other subject }\end{array}$ & 0 & 1 & 1 \\
\hline & New contracts & 0 & 1 & 1 \\
\hline
\end{tabular}


TABLE 14 - continued

\begin{tabular}{|c|c|c|c|c|}
\hline Announcement type & Topics & Before & After & Total \\
\hline & $\begin{array}{l}\text { Products and services } \\
\text { commercial operation } \\
\text { new contracts other } \\
\text { subject }\end{array}$ & 53 & 1 & 54 \\
\hline & $\begin{array}{l}\text { Products and services } \\
\text { commercial operation } \\
\text { new contracts }\end{array}$ & 72 & 97 & 169 \\
\hline $\begin{array}{l}\text { Commercial operation } \\
\text { total }\end{array}$ & & 125 & 108 & 233 \\
\hline \multirow[t]{4}{*}{ Income } & $\begin{array}{l}\text { Other subject products } \\
\text { and services income }\end{array}$ & 163 & 5 & 168 \\
\hline & $\begin{array}{l}\text { Other subject products } \\
\text { and services income } \\
\text { commerciële } \\
\text { aankondigingen }\end{array}$ & 2 & 0 & 2 \\
\hline & $\begin{array}{l}\text { Products and services } \\
\text { income }\end{array}$ & 574 & 772 & 1,346 \\
\hline & $\begin{array}{l}\text { Products and services } \\
\text { income commerciële } \\
\text { aankondigingen }\end{array}$ & 1 & 0 & 1 \\
\hline Income total & & 740 & 777 & 1,517 \\
\hline \multirow[t]{5}{*}{ Corporate life } & Corporate life & 0 & 1 & 1 \\
\hline & Journal/appointments & 0 & 7 & 7 \\
\hline & $\begin{array}{l}\text { Journal/appointments } \\
\text { corporate life }\end{array}$ & 18 & 152 & 170 \\
\hline & $\begin{array}{l}\text { Journal/appointments } \\
\text { other subject } \\
\text { corporate life }\end{array}$ & 2 & 1 & 3 \\
\hline & $\begin{array}{l}\text { Other subject } \\
\text { journal/appointments } \\
\text { corporate life }\end{array}$ & 1 & 0 & 1 \\
\hline Corporate life total & & 21 & 161 & 182 \\
\hline \multirow[t]{3}{*}{ Board/general meeting } & $\begin{array}{l}\text { General meeting/board } \\
\text { meeting }\end{array}$ & 87 & 77 & 164 \\
\hline & $\begin{array}{l}\text { General meeting/board } \\
\text { meeting other subject }\end{array}$ & 27 & 1 & 28 \\
\hline & $\begin{array}{l}\text { General meeting/board } \\
\text { meeting other subject } \\
\text { products and services } \\
\text { income }\end{array}$ & 2 & 0 & 2 \\
\hline
\end{tabular}


TABLE 14 - continued

\begin{tabular}{|c|c|c|c|c|}
\hline Announcement type & Topics & Before & After & Total \\
\hline & $\begin{array}{l}\text { Other subject general } \\
\text { meeting/board } \\
\text { meeting }\end{array}$ & 1 & 0 & 1 \\
\hline $\begin{array}{l}\text { Board/general meeting } \\
\text { total }\end{array}$ & & 117 & 78 & 195 \\
\hline \multirow[t]{3}{*}{ Meetings/events } & Meetings/events & 14 & 26 & 40 \\
\hline & $\begin{array}{l}\text { Meetings/events other } \\
\text { subject }\end{array}$ & 6 & 0 & 6 \\
\hline & $\begin{array}{l}\text { Other subject } \\
\text { meetings/events }\end{array}$ & 1 & 0 & 1 \\
\hline Meetings/events total & & 21 & 26 & 47 \\
\hline \multirow[t]{9}{*}{ Other } & (blank) & 1 & 2 & 3 \\
\hline & Change in capital & 0 & 1 & 1 \\
\hline & New establishment & 0 & 1 & 1 \\
\hline & $\begin{array}{l}\text { Other financial } \\
\text { transaction }\end{array}$ & 0 & 5 & 5 \\
\hline & Other subject & 738 & 554 & 1,292 \\
\hline & $\begin{array}{l}\text { Other subject change in } \\
\text { capital }\end{array}$ & 0 & 1 & 1 \\
\hline & Products and services & 0 & 3 & 3 \\
\hline & $\begin{array}{l}\text { Sales Alliances and } \\
\text { agreements takeover } \\
\text { bids joint venture } \\
\text { mergers, acquisitions, } \\
\text { transfers }\end{array}$ & 0 & 1 & 1 \\
\hline & Trends, analyses & 0 & 1 & 1 \\
\hline Other total & & 739 & 569 & 1,308 \\
\hline Total & & 2,104 & 2,875 & 4,979 \\
\hline
\end{tabular}

Open Access This article is distributed under the terms of the Creative Commons Attribution Noncommercial License which permits any noncommercial use, distribution, and reproduction in any medium, provided the original author(s) and source are credited.

\section{REFERENCES}

Ahmed, A.S. and R.A. Schneible (2007), 'The Impact of Regulation Fair Disclosure on Investors' Prior Information Quality: Evidence from an Analysis of Changes in Trading Volume and Stock Price Reactions to Earnings Announcements', Journal of Corporate Finance, 13(2/3), pp. 282-299. 
Atiase, R.K. (1980), Predisclosure informational asymmetries, firm capitalization, financial reports, and security price behaviour. Unpublished Ph.D. dissertation, University of California, Berkeley.

Atiase, R.K. (1987), 'Market Implications of Predisclosure Information: Size and Exchange Effects'. Journal of Accounting Research, 25(1), pp. 168-176.

Autoriteit Financiële Markten. (2007). Ruim een jaar toezicht op marktmisbruik. Autoriteit Financiële Markten.

Bainbridge, S.M. (1999), Securities law: Insider trading. New York, Foundation Press.

Beny, L.N. (2005), 'Do Insider Trading Laws Matter? Some Preliminary Comparative Evidence'. American Law and Economics Review, 7(1), pp. 144-183.

Beny, L.N. (2007), 'Insider Trading Laws and Stock Markets Around the World: An Empirical Contribution to the Theoretical Law and Economics Debate'. Journal of Corporation Law, 32(2), pp. 237-300.

Berument, H., A. Inamlik and H. Kiymaz (2004), 'Borsa degiskenliginde haftanin gun etkisi: Istanbul Menkul Kiymetler Borsasi'. (The Day of the Week Effect on Stock Return and Volatility: The Case of Istanbul Stock Exchange [ISE]. With English summary.), Iktisat Isletme ve Finans, 19(223), pp. 91-102.

Berument, H. and H. Kiymaz (2001), 'The Day of the Week Effect on Stock Market Volatility'. Journal of Economics and Finance, 25(2), pp. 181-193.

Bhattacharya, U. and H. Daouk (2002). 'The World Price of Insider Trading', Journal of Finance, 57(1), pp. 75-108.

Bhattacharya, U., H. Daouk, B. Jorgenson and C.-H. Kehr (2000), 'When an Event is Not an Event: The Curious Case of an Emerging Market', Journal of Financial Economics, 55(1), pp. 69-101.

Brown, S.J. and J.B. Warner (1985), 'Using Daily Stock Returns: The Case of Event Studies', Journal of Financial Economics, 14(1), pp. 3-31.

Collver, C.D. (2007), 'Is There Less Informed Trading After Regulation Fair Disclosure'? Journal of Corporate Finance, 13(2/3), pp. 270-281.

Dubow, B. and N. Monteiro (2006), Measuring market cleanliness. Financial Services Authority.

Elliott, J., D. Morse and G. Richardson (1984), 'The Association Between Insider Trading and Information Announcements', RAND Journal of Economics, 15(4), pp. 521-536.

Hallock, K.F. and F. Mashayekhi (2003), Are formal corporate news announcements still newsworthy?: Evidence from 30 years of US data on earnings, splits, and dividends. University of Illinois.

Halpern, P.J. (1973), 'Empirical Estimates of the Amount and Distribution of Gains to Companies in Mergers'. Journal of Business, 46(4), pp. 554-575.

Jaffe, J.P. (1974), 'Special Information and Insider Trading', Journal of Business, 47(3), pp. 410428.

Jain, P.C. (1988). 'Response of Hourly Stock Prices and Trading Volume to Economic News', Journal of Business, 61(2), pp. 219-231.

Kabir, R. and T. Vermaelen (1996). 'Insider Trading Restrictions and the Stock Market: Evidence from the Amsterdam Stock Exchange', European Economic Review, 40(8), pp. 1591-1603.

Keown, A.J. and J.M. Pinkerton (1981), 'Merger Announcements and Insider Trading Activity: An Empirical Investigation', Journal of Finance, 36(4), pp. 855-869.

Kiymaz, H. and H. Berument (2003), 'The Day of the Week Effect on Stock Market Volatility and Volume: International Evidence', Review of Financial Economics, 12(4), pp. 363-380.

MacKinlay, A.C. (1997), 'Event Studies in Economics and Finance', Journal of Economic Literature, 35(1), pp. 13-39. 
Meulbroek, L.K. (1992), 'An Empirical Analysis of Illegal Insider Trading', Journal of Finance, 47(5), pp. 1661-1699.

Monteiro, N., Q. Zaman and S. Leitterstorf (2007), Updated measurement of market cleanliness. Financial Services Authority.

Polinsky, A.M. and S. Shavell (2000), 'The Economic Theory of Public Enforcement of Law', Journal of Economic Literature, 38(1), pp. 45-76.

Sanders Jr, R.W. and J.S. Zdanowicz (1992), 'Target Firm Abnormal Returns and Trading Volume around the Initiation of Change in Control Transactions', Journal of Financial and Quantitative Analysis, 27(1), pp. 109-129.

Wong, E. (2002), Investigation of market efficiency: An event study of insider trading in the stock exchange of Hong Kong. Unpublished Thesis, Stanford University, Stanford. 